\title{
What Is an International Crime? (A Revisionist History)
}

\author{
Kevin Jon Heller*
}

\begin{abstract}
The question "what is an international crime?" has two aspects. First, it asks us to identify which acts qualify as international crimes. Second, and more fundamentally, it asks us to identify what is distinctive about an international crime.

Some disagreement exists concerning the first issue, particularly with regard to torture and terrorism. But nearly all states, international tribunals, and ICL scholars take the same position concerning the second issue, insisting that an act qualifies as an international crime if -and only if -that act is universally criminal under international law.

This definition of an international crime leads to an obvious question: how exactly does an act become universally criminal under international law? One answer, the "direct criminalization thesis" (DCT), is that certain acts are universally criminal because they are directly criminalized by international law itself, regardless of whether states criminalize them. Another answer, the "national criminalization thesis" (NCT), rejects the idea that international law directly criminalizes particular acts. According to the NCT, certain acts are universally criminal because international law obligates every state in the world to criminalize them.

This Article argues that if we take positivism seriously, as every international criminal tribunal since Nuremberg has insisted we must, the NCT provides the only coherent explanation of how international law can deem certain acts to be universally criminal.
\end{abstract}

\section{INTRODUCTION}

The question posed by the title of this Article has two aspects. First, it asks us to identify which acts qualify as international crimes. Second, and more fundamentally, it asks us to identify what is distinctive about an international crime-what makes an international crime different than a transnational crime or an ordinary domestic crime.

\section{A. The Nature of International Crimes}

The descriptive aspect of the question is easily answered: nearly all international criminal law ("ICL") scholars agree that the category of "true" international crimes is limited to war crimes, crimes against humanity,

* Associate Professor of Public International Law, University of Amsterdam and Returning Visiting Professor of Criminal Law, SOAS, University of London. 
genocide, and aggression. ${ }^{1}$ A few scholars would add acts such as torture ${ }^{2}$ and terrorism ${ }^{3}$ to the list, but they remain in the distinct minority.

At first glance, there appears to be little consensus concerning the conceptual aspect of the question. After all, scholars often claim that there is no agreement concerning what makes an international crime distinctive. According to O'Keefe, for example, "[n]o common understanding, let alone common definition" of an international crime exists. ${ }^{4}$ Similarly, Bassiouni says that " $[t]$ he writings of scholars are uncertain, if not tenuous, as to what they deem to be the criteria justifying the establishment of crimes under international law." 5

But that is not actually true. In fact, nearly all scholars share a common understanding of what makes an international crime distinctive: namely, that it involves an act that international law deems universally criminal. The international law requirement is what distinguishes an international crime from a domestic crime: although some acts that qualify as domestic crimes are universally criminal — murder, for example ${ }^{6}$ - their universality derives not from international law, but from the fact that every state in the world has independently decided to criminalize them. And the universality requirement is what distinguishes an international crime from a transnational crime: although the criminality of a transnational crime emanates from international law - a treaty requiring a particular act to be domestically criminalized-international law does not deem a transnational crime universally criminal, because it leaves the decision to criminalize to states themselves. If a state does not want to criminalize the commission of a transnational crime, it can simply decline to ratify the treaty in question.

\section{B. The Basis of Universality}

Defining an international crime as an act that international law deems universally criminal, however, raises a critical question: how exactly does an act such as genocide become universally criminal under international law? Two very different answers to that question are possible, and the goal of this article is to adjudicate between them. The first answer, what I call the "direct criminalization thesis" (DCT), is that certain acts are universally criminal because they are directly criminalized by international law itself,

1. See, e.g., Terje Einarsen, The Concept of Universal Crimes in International Law 21 (2012)

2. See, e.g., Roger O’Keefe, International Criminal Law 47 (2015).

3. See, e.g., Antonio Cassese et al., Cassese's international Criminal Law 148 (3rd ed. 2003); cf. Special Tribunal for Lebanon, Interlocutory Decision on the Applicable Law, Case No. STL-11-01/I, para. 102 (Feb. 16, 2011).

4. O'KeEFe, supra note 2, at 47.

5. M. Cherif Bassiouni, International Crimes: The Ratione Materiae of International Criminal Law, in I International Criminal Law: Sources, Subjects, and Content 142 (M. Cherif Bassiouni ed., 3rd ed. 2008).

6. See John Mikhail, Is the Probibition of Homicide Universal?, 75 Brook. L. Rev. 497, 503 (2009). 
regardless of whether states criminalize them. All modern ICL scholars take this position. Cassese, for example, says that the international crimes are "premised on the general notion that international legal prescriptions are capable of imposing obligations directly on individuals, without the intermediary of the state wielding authority over such individuals." ${ }^{\prime 7}$ Cryer similarly notes that "the fundamental point to understand about these crimes" is that "States have decided that international law, in exceptional circumstances, ought to bypass the domestic legal order, and criminalise behaviour directly." 8 And Triffterer says that what is distinctive about international criminality is that "individuals can be punished even if there exists no corresponding punishability under their domestic law and jurisdiction or any other national legal system purporting to exercise jurisdiction." 9 These examples could be multiplied indefinitely. ${ }^{10}$

The second answer, what I call the "national criminalization thesis" (NCT), rejects the idea that international law bypasses domestic law by directly criminalizing particular acts. According to the NCT, certain acts are universally criminal under international law, and thus qualify as true international crimes, because international law obligates every state in the world to criminalize and prosecute them. ${ }^{11}$ No modern ICL scholar has taken this approach, although intimations of it date back to Grotius.

Which thesis is correct? This Article argues that it depends on whether we adopt a naturalist or positivist approach to international law. Naturalism is a deductive methodology, deriving the basic principles of international law "not from any deliberate human choice or decision, but from principles of justice which [have] a universal and eternal validity and which [can] be

7. CASsese, supra note 3, at 9 .

8. Robert Cryer, The Doctrinal Foundations of International Criminalization, in INTERNATIONAL CRIMINAL LAW, supra note 5, at 108.

9. Otto Triffterer, Preliminary Remarks, in Commentary on the Rome Statute of the International Criminal Court: Observers' Notes, Article by Article 25 (Otto Triffterer ed., 2008).

10. See, e.g., Claus Kress, International Criminal Law, para. 10, Max Planck EnCyClopedia of PubLIC InTERnATIONAL LAw (2009), http://www.uni-koeln.de/jur-fak/kress/Materialien/Chef/HP882010/ ICL.pdf ("International criminal law strictu sensu establishes criminal responsibility directly under international law.”); Neil Boister, Transnational Criminal Law?, 14 Eur. J. INT'L L. 953, 962 (2003) ("Uniquely, however, these core offences provide for individual criminal liability for their violation, even in the absence of a domestic prohibition, and are now subject to a direct enforcement scheme where the individual may be prosecuted before a permanent international criminal court."); KAI Ambos, TreatisE on International Criminal Law: Foundations and General Part 54 (2013) ("ICL stricto sensu . . comprises the totality of international law norms of a penal nature which conjoin typical legal consequences of criminal law with a decisive conduct - namely the international crime - and as such can be applied directly."); Yoram Dinstein, International Criminal Law, 20 IsR. L. Rev. 206, 207 (1985) ("When an individual human being contravenes an international duty binding him directly, he commits an international offence and risks his life, liberty or property."); Bruno Simma \& Andreas L. Paulus, The Responsibility of Individuals for Human Rights Abuses in Internal Conflicts: A Positivist View?, 93 AM. J. INT'L L. 302, 308 (1999) (arguing that "truly international" crimes are predicated on "rules establishing individual criminal responsibility directly at the international level”).

11. Except where required, I will refer to this joint obligation simply as an "obligation to criminalize." 
discovered by pure reason." 12 Positivism, by contrast, derives international legal rules inductively, on the basis of what states do and say. ${ }^{13}$

Every international criminal tribunal has insisted that international crimes are positivist, not naturalist, phenomena. ${ }^{14}$ As this Article will demonstrate, however, no extant theory of positivism-not even so-called "instant custom" - is capable of justifying the idea that certain acts are directly criminalized by international law. On the contrary, if we take positivism seriously, the NCT provides the only coherent explanation of how international law can deem certain acts to be universally criminal. Maintaining fidelity to the idea of direct criminalization thus requires rejecting positivism in favor of naturalism—with all of naturalism's inherent limitations.

\section{Roadmap}

This Article is divided into five parts. Part II shows that nearly every definition of an international crime offered by states, international tribunals, and ICL scholars emphasizes the universal criminality of the act in question under international law. Part III explains why the most promising material sources for direct criminalization, such as multilateral treaties and unanimously-adopted General Assembly resolutions, do not provide a sufficient positivist basis for the DCT. Part IV demonstrates that the nationalcriminalization thesis has a much stronger, though still not incontestable, positivist foundation. Part V explores how adopting the NCT requires us to reconceptualize the traditional distinction between international and transnational crimes, because a number of transnational crimes have an even stronger positivist claim to international status than some of the international crimes, particularly aggression. Finally, Part VI reflects on the implications of the analysis provided in the previous parts, focusing on the disquieting idea that no conception of an international crime, not even the NCT's, may be able to completely escape the specter of naturalism.

12. Akehurst's Modern Introduction to International Law 15 (Peter Malanczuk ed., 7th ed. 1997); see also Alexander Orakhelashvili, Natural Law and Customary Law, 68 ZeITSCHRIFT Für Ausländisches ÖFfEntliches Recht \& VÖlKERRECHT 69, 70-71 (2008) ("The concept of natural law refers to rules and principles deducible from nature, reason, or the idea of justice."); Cryer, Doctrinal, supra note 8, at 111 (noting that natural law theories deduce the law "from a priori principles, grounded either on a theological base, an assumed consensus of rational thought, or a (similarly assumed) social necessity.").

13. See, e.g., Simma \& Paulus, supra note 10, at 304 ("Positivism can also be understood as the strict separation of the law in force, as derived from formal sources that are part of a unified system of law, from nonlegal factors such as natural reason, moral principles and political ideologies.").

14. See, e.g., EINARSEN, supra note 1, at 116 (IMT); Robert Cryer, The Philosophy of International Criminal Law, in History of International Law 242 (Alexander Orakhelashvili ed., 2011) (IMTFE); id. at 253 (SCSL) id. at 253-54 (ICC); Birgit Schlütter, Developments in Customary International Law: Theory and the Practice of the International Court of Justice and the International Ad Hoc Criminal Tribunals for Rwanda and Yugoslavia 98 (2010) (ICTY \& ICTR). For the Special Tribunal for Lebanon, see the Interlocutory Decision on the Applicable Law, supra note 3, at para. 85. 


\section{UNIVERSAL CRIMINALITY}

As noted above, O'Keefe believes that there is no common definition of an international crime. It is true that courts and scholars have offered very different formulations in the decades since Nuremberg. Beneath the definitional welter, however, lies a common assumption about what makes an international crime distinctive: namely, that it involves an act that international law deems universally criminal. International crimes are universal crimes; they are criminal and punishable no matter where in the world they are committed.

\section{A. States}

States have consistently affirmed the universality of international crimes. Most importantly, in terms of state practice, ${ }^{15}$ nearly 150 states have adopted legislation that allows their courts to exercise universal jurisdiction over war crimes, crimes against humanity, genocide, or aggression. ${ }^{16}$ Universal jurisdiction is predicated on the idea of universal criminality, given that it permits states to prosecute acts "without regard to where the crime was committed, the nationality of the alleged or convicted perpetrator, the nationality of the victim, or any other connection to the state exercising such jurisdiction." ${ }^{17}$ If international crimes can be prosecuted no matter where they are committed, they are criminal everywhere.

State practice concerning universal jurisdiction is also routinely accompanied by statements-opinio juris-explicitly affirming that international crimes are criminal no matter where they are committed. A number of states focus on the nature of the acts themselves: Belarus argues that international crime[s] are "universally condemned," 18 while Italy says they are "universally abhorred;" 19 Brazil claims that international crimes "shock $[\ldots]$ the

15. See International Law Commission, Identification of Customary International Law, Text of the Draft Conclusions Provisionally Adopted by the Drafting Committee 2, 68th Session of the ILC, UN Doc. A/CN.4/ L.872 (May 30, 2016); International Law Association, Statement of Principles Applicable to the Formation of General Customary International Law 14, Report of the Sixty-Ninth Conference (2000) (noting that domestic legislation counts as state practice).

16. Amnesty International, Universal Jurisdiction: A Preliminary Survey of Legislation Around the World2012 Update 12 (2012).

17. Universal JURISDiction: NATIONAL COURTS AND THE PROSECUTION OF SERIOUS CRIMES UNDER INTERNATIONAL LAW 21 (Stephen Macedo ed., 2004).

18. Statement Submitted by Belarus, reply to U.N. Secretary-General, The Scope and Application of the Principle of Universal Jurisdiction, Sixty-Fifth Session of the General Assembly U.N. Doc. A/65/181 (July 29, 2010) [hereinafter Sixty-Fifth U.N. G.A. on Universal Jurisdiction] at 1, http://www.un.org/en/ga/ sixth/65/ScopeAppUniJuri_StatesComments/Belarus_E.pdf.

19. Statement Submitted by Italy, reply to U.N. Secretary-General, The Scope and Application of the Principle of Universal Jurisdiction, Sixty-Sixth Session of the General Assembly U.N. Doc. A/66/93 (June 20, 2011) [hereinafter Sixty-Sixth U.N. G.A. on Universal Jurisdiction] at 2, http://www.un.org/en/ga/ sixth/66/ScopeAppUniJuri_StatesComments/Italy.pdf. 
conscience of all humanity," 20 and South Africa claims that international crimes are "crimes against mankind" because they offend "the international community as a whole." 21 Other states focus more on the universal punishability of international crimes: Kenya says universal jurisdiction exists to permit "the trial of international crimes committed by anybody, anywhere in the world," 22 an idea that Argentina claims is "universally accepted," $23 \mathrm{El}$ Salvador insists that international crimes protect values "which must not be disregarded under any circumstances"24; and Chile simply describes the existence of universal jurisdiction as reflecting the "universalization of justice." 25 And still other states emphasize both sides of the equation. Belgium, for example, insists that because international crimes are "universally condemned," they "cannot go unpunished and must therefore be universally suppressed." 26

Domestic courts applying international law have also routinely affirmed that international crimes are universally criminal. Most famously, in Eichmann, the District Court of Jerusalem invoked "[t] he universal character of the crimes in question" to justify its right to punish Eichmann for crimes against humanity committed before the State of Israel even existed. ${ }^{27}$ The US Court of Appeals for the Sixth Circuit applied the same analysis in Demjanjuk, noting that the crimes for which Israel wanted the defendant extradited have been "universally recognized and condemned by the community of nations." 28 Similarly, In Pinochet No. 3, Lord Browne-Wilkinson wrote for the majority that "[c]rimes against humanity are crimes not against a state but against individuals and are triable anywhere." ${ }^{29}$ Lord Phillips agreed, adding that because "[t]here are some categories of crime of such gravity that they shock the consciousness of mankind and cannot be

20. U.N. GAOR, 69th Sess., 11th mtg. of the 6th Comm. at 6, U.N. Doc. A/C.6/69/SR.11 (Nov. 6, 2014), bttps://documents-dds-ny.un.org/doc/UNDOC/GEN/N14/570/17/PDF/N1457017.pdf?OpenElement.

21. Statement Submitted by South Africa, reply to Sixty-Fifth U.N. G.A. on Universal Jurisdiction, supra note 18 , at 2 .

22. Statement Submitted by Kenya, reply to Sixty-Fifth U.N. G.A. on Universal Jurisdiction, supra note 18, at 1. http://www.un.org/en/ga/sixth/65/ScopeAppUniJuri_StatesComments/Kenya.pdf.

23. Statement Submitted by Argentina, reply to Sixty-Sixth U.N. G.A. on Universal Jurisdiction supra note 19, at 1. http://www.un.org/en/ga/sixth/66/ScopeAppUniJuri_StatesComments/Argentina $\% 20$ (S\%20to\%20E).pdf.

24. Statement Submitted by El Salvador, reply to Sixty-Sixth U.N. G.A. on Universal Jurisdiction supra note 19, at 4 . http://www.un.org/en/ga/sixth/66/ScopeAppUniJuri_StatesComments/ El\%20Salvador\%20(S\%20to\%20E).pdf.

25. Statement Submitted by Chile, reply to Sixty-Fifth U.N. G.A. on Universal Jurisdiction, supra note 18, at 3. http://www.un.org/en/ga/sixth/65/ScopeAppUniJuri_StatesComments/Chile_E.pdf.

26. Statement Submitted by Belgium, reply to Sixty-Fifth U.N. G.A. on Universal Jurisdiction, supra note 18, at 1. http://www.un.org/en/ga/sixth/65/ScopeAppUniJuri_StatesComments/Belgium_E.pdf.

27. CrimC (Jer) 40/61 Attorney General v. Adolf Eichmann, If 11 (1961) (Isr.).

28. Demjanjuk v. Petrovsky, 776 F.2d 571, 582-83 (6th Cir. 1985).

29. Reg. v Bow Street Magistrate, Ex p. Pinochet (No 3), 1 A.C. [2000] 157 (Opinion of Lord BrowneWilkinson). 
tolerated by the international community. . . [a]ny individual who commits such a crime offends against international law." 30

\section{B. ICTs}

The universality of international crimes has been a central theme in international jurisprudence. One of the most famous statements in ICL is the Nuremberg Military Tribunal's insistence in the Hostage case that "[a]n international crime is such an act universally recognized as criminal." ${ }^{31}$ The Special Tribunal for Lebanon (STL) uses similar language, connecting international criminality to the universality of customary international law: "international crimes are those offences that are considered so heinous and contrary to universal values that the whole community condemns them through customary rules." 32 And the ICTY makes an even stronger claim, insisting that international crimes are "universally condemned wherever they occur," ${ }_{33}$ because they are "peremptory norms of international law or jus cogens." 34

The Rome Statute does not explicitly state that international crimes are criminal no matter where they are committed. But universality is nevertheless implicit in the Preamble's insistence that international crimes "deeply shock the conscience of humanity" and "threaten the peace, security and well-being of the world." 35 The Preamble also emphasizes that "the most serious crimes of concern to the international community as a whole must not go unpunished," 36 reinforcing the idea that (at least) war crimes, crimes against humanity, and genocide are universally criminal. ${ }^{37}$ If international crimes are not universally criminal, they are not universally punishable.

\section{The ICJ}

The ICJ has rarely addressed the nature of international crimes. The primary exception is its 1951 Genocide Advisory Opinion, in which the Court adopted a universalizing explanation of why genocide is an international crime:

30. Id. at 243 (Opinion of Lord Phillips).

31. United States of America $v$ Wilhelm List et al. (Hostage), XI Law Reports of Trials OF War CRIMINALS 1241 (1949).

32. STL Interlocutory Decision, supra note 3, para 134.

33. Prosecutor v. Furundžija, Case No. IT-95-17/1, Judgment, 156 (Dec. 10, 1998).

34. Prosecutor v Kupreškić, Case No. IT-95-16-T, Judgment, para. 520 (Int'l Crim. Trib. for the Former Yugoslavia Jan. 14, 2000). "Jus cogens" refers to a small class of fundamental norms of international law that are non-derogable-that prohibit states from assuming treaty obligations inconsistent with the norm. See, e.g., AKehurst, supra note 12, at 57-58.

35. Rome Statute of the International Criminal Court, pmbl., July 17, 1998, 2187 U.N.T.S. 3 [hereinafter Rome Statute].

36. Id., Preamble, para. 4.

37. See William A. Schabas, An Introduction to the International Criminal Court 83 (3rd ed., 2007). 
The origins of the Convention show that it was the intention of the United Nations to condemn and punish genocide as "a crime under international law" involving a denial of the right of existence of entire human groups, a denial which shocks the conscience of mankind and results in great losses to humanity, and which is contrary to moral law and to the spirit and aims of the United Nations. The first consequence arising from this conception is that the principles underlying the Convention are principles which are recognized by civilized nations as binding on States, even without any conventional obligation. ${ }^{38}$

The idea that genocide is universally criminal is woven into the fiber of this statement. Genocide not only "shocks the conscience of mankind" and is contrary "to the spirit and aims of the United Nations," it even violates "moral law." ${ }^{39}$ It would be a strange moral law that prohibited the commission of genocide in some states but not in others. Moreover, like the STL and the ICTY, the ICJ emphasizes that the obligation to criminalize genocide does not only apply to states that have freely chosen to ratify the Genocide Convention, but also binds all states equally as a matter of general international law-even those "without any conventional obligation." 40

\section{The ILC}

The International Law Commission (ILC) has repeatedly affirmed that international crimes are criminal no matter where they are committed. The idea of universality is inherent in the very title of its Draft Codes: "offences against the peace and security of mankind." ${ }^{41}$ It is difficult to see how an act that is inimical to the peace and security of mankind could be criminal in some places but not in others-an act either threatens peace and security or it does not. Indeed, in his Second Report on what would become the 1996 Draft Code, Special Rapporteur Doudou Thiam stated that such acts have an "international dimension" precisely because they "affect peoples, races, nations, cultures, civilizations and mankind" and thus "conflict with universal values." 42

The universality of international crimes was equally foregrounded in Article 19 of the ILC's 1980 version of the Draft Articles on Responsibility of States for Internationally Wrongful Acts (DASR), which defined an "international crime" as "[a]n internationally wrongful act which results from the

38. Reservations to Convention on Prevention and Punishment of Crime of Genocide, Advisory Opinion, 1951 I.C.J. Rep. 23 (May 28) (citation omitted).

39. Id.

40. $I d$.

41. Second Report on the Draft Code of Offences against the Peace and Security of Mankind, by Mr. Doudou Thiam, Special Rapporteur, U.N. Doc. A/CN.4/377 \& Corr. 1 (1984), reprinted in [1984] 2 Y.B. INT'L L. Comm'N 89, 89, U.N. Doc. A/CN.4/SER.A/1984/Add.1 (Part 1).

42. Id. at para. 8 . 
breach by a state of an international obligation so essential for the protection of the fundamental interests of the international community that its breach is recognized as a crime by that community as a whole." 43 That article, which was based on "the feeling and conviction of the international community that certain interests and values are of primordial importance to it," 44 was ultimately put to one side, but not because states took issue with the idea that international law could universally criminalize certain acts. Instead, the ILC concluded that the universalizing position of Article 19 might be better addressed by developing the concepts of jus cogens and obligations erga omnes. ${ }^{45}$

\section{E. Scholars}

ICL scholars have been even more unwavering in their insistence that international crimes are universally criminal. ${ }^{46}$ May says "there are some principles that transcend national borders and achieve universal binding force. In international law, some crimes so clearly harm the international community that they must be proscribed in all societies." ${ }^{47}$ Cassese makes a similar claim, arguing that because international crimes involve violations of rules "intended to protect values considered important by the whole international community," they are "consequently binding on all states and individuals." 48 According to Gaeta, ICL "has its roots in the gradual emergence of a set of 'supra-national' values, proper to the international community as a whole, that must be safeguarded against those states that-through their individual organs or their whole apparatus-disregard them." 49 Freeland likewise emphasizes that the internationalization of justice "recognizes that

43. Report of the International Law Commission on the Work of Its Thirty-Second Session, Art. 19(2), UN Doc. A/35/10 (1980), reprinted in [1980] 2 Y.B. INT'L L. CoMm'N 1, 38, U.N. Doc. A/CN.4/ SER.A/1980/Add.1 (Part 2).

44. Georges Abi-Saab, The Concept of "International Crimes" and Its Place in Contemporary International Law, in International Crimes of State: A Critical Analysis of the IlC's Draft Article 19 on State Responsibility 141, 147 (Joseph H.H. Weiler et al. eds., 1989).

45. Report of the International Law Commission on the Work of its Fiftieth Session, UN Doc. A/53/ 10; see also Gennady M. Danilenko, Law-Making in the International Community (1993) ("The jus cogens concept was regarded by [the ILC] as the best means for reconciling the requirement for the universality of the offences and of the rule of law with the consensual nature of the proposed international instrument whose adoption would require the consent of states.").

46. The only exceptions are scholars who believe international crimes can be created by treaty. See, e.g., O'KeEFE, supra note 2, at 56 (arguing that "offences defined by international law which give rise to criminal responsibility under municipal law alone” also qualify as international crimes); STEVEN R. Ratner et al., Accountability for Human Rights Atrocities in International Law: Beyond THE Nuremberg LEGACY 12 (3d ed. 2009) (arguing that "a violation of international law becomes an international crime if the global community intends through any of those strategies (regardless of whether they are implemented through treaty, custom, or other prescriptive method) to hold individuals directly responsible for it").

47. Larry May, Crimes Against Humanity: A Normative Account 24 (2005).

48. Antonio Cassese, International Law 436 (2005) (emphasis in original omitted).

49. Paola Gaeta, International Criminal Law, in InTERnATIONAL LAw FOR INTERnAtional RelaTIONs 259 (Basak Cali ed., 2010). 
there are certain norms of international criminal law that transcend national boundaries and, like fundamental human rights norms, are regarded as universal in acceptance and thus should be universal in application." 50 Werle and Jessberger rely on the "universal nature of international crimes" to explain why states are permitted to exercise universal jurisdiction over them, ${ }^{51}$ while Meron reaches the same conclusion based on the fact that international crimes are "recognized by the community of nations as of universal concern" and attract "universal condemnation." 52 And both Einarsen and Colangelo simply refer to international crimes as "universal crimes." 53

Cryer is on firm ground, then, when he claims that "the universal applicability of international criminal law is now a commonplace assumption." 54 Indeed, although it is possible to defend the idea that some international crimes are not universally criminal, ${ }^{55}$ it would be surprising if many scholars took the position that international crimes could be illegal in some places but not in others. As Koskenniemi says, "it is inherently difficult to accept the notion that states are legally bound not to engage in genocide, for example, only if they have ratified and not formally denounced the 1948 Genocide Convention." 56

This understanding of an international crime, of course, necessarily assumes that international law is capable of deeming certain acts universally criminal. But how does that happen? How do certain acts become universally criminal under international law? The direct-criminalization thesis and the national-criminalization thesis provide very different answers to that question.

\section{THE DIRECT CRIMINALIZATION THESIS}

As noted earlier, the DCT defines an international crime as an act that is directly criminalized by international law itself, irrespective of domestic criminalization. That thesis finds its seminal expression in the judgment of the International Military Tribunal at Nuremberg (IMT):

Crimes against international law are committed by men, not by abstract entities, and only by punishing individuals who commit

50. Steven Freeland, The Internationalization of Justice-A Case for the Universal Application of International Criminal Law Norms, 4 N.Z. Y.B. INT'L L. 45, 47 (2007). (emphasis in original omitted).

51. Gerhard Werle \& Florian Jessberger, Principles of International Criminal Law 73 (3d ed. 2014).

52. Theodor Meron, International Criminalization of Internal Atrocities, 89 AM. J. INT'L L. 554, 570 (1995)

53. See EINARSEN, supra note 1, at 6; Anthony J. Colangelo, The Legal Limits of Universal Jurisdiction, 7 VA. J. INT'L L. 149, 160 (2006-2007).

54. Robert Cryer, Prosecuting International Crimes: Selectivity and the International Criminal Law Regime 12 (2005).

55. See, e.g., O'KeEFE, supra note 2, at 56 (taking the position that any crime "defined by international law, whether customary or conventional," qualifies as an international crime).

56. Martti Koskenniemi, The Pull of the Mainstream, 88 MicH. L. Rev. 1946, 1946 (1990). 
such crimes can the provisions of international law be enforced. . individuals have international duties which transcend the national obligations of obedience imposed by the individual State. ${ }^{57}$

The basic assumption of the DCT is that there is no relationship between international criminalization and domestic criminalization: an act can be criminal under international law even if it is legal under domestic law. That is what the IMT meant when it said that individuals have "international duties which transcend. . . national obligations." Indeed, in the decades since Nuremberg, the ILC has repeatedly emphasized the irrelevance of domestic criminalization to international criminalization. The 1950 "Principles of International Law Recognized in the Charter of the Nürnberg Tribunal and in the Judgment of the Tribunal"- the famous Nuremberg Principles-provide that "[t]he fact that internal law does not impose a penalty for an act which constitutes a crime under international law does not relieve the person who committed the act from responsibility under international law." 58 The 1991 Draft Code of Crimes against the Peace and Security of Mankind affirms that "[t]he characterization of an act or omission as a crime against the peace and security of mankind is independent of internal law. The fact that an act or omission is or is not punishable under internal law does not affect this characterization." ${ }^{9}$ And most clearly of all, the 1996 Draft Code states categorically that "[C]rimes against the peace and security of mankind are crimes under international law and punishable as such, whether or not they are punishable under national law." ${ }^{60}$

The DCT provides a coherent account of how international law could deem a particular act universally criminal. If international law is superior to national law- - individuals have international duties which transcend. . . national obligations" - an act that international law considers criminal would be criminal even if the territorial state considered it legal. Indeed,

57. IMT, Judgment of 1 October 1946, in 22 The Trial of German Major War Criminals, Proceedings of the International Military Tribunal Sitting at Nuremberg, Germany 447 (1946) [hereinafter "IMT Judgment"].

58. Principles of International Law Recognized in the Charter of the Nürnberg Tribunal and in the Judgment of the Tribunal, Principle 2 (Aug. 2, 1950), 1950 Y.B. Int'l L. Comm'n, UN Doc. A/CN.4/ SER.A/1950/Add.1.

59. Draft Code of Crimes Against the Peace and Security of Mankind, Text of Draft Articles Provisionally Adopted by the Commission on First Reading, in Report of the International Law Commission on the Work of Its Forty-Third Session, Art. 2, UN Doc. A/CN.4/L.459 [and corr.1] and Add.1 at 187 (1991)

60. Draft Code of Crimes Against the Peace and Security of Mankind with Commentaries, Art. 1(2), in Report of the International Law Commission on the Work of its Forty-Eighth Session, UN GAOR, 51st Sess., Supp. No. 10, UN Doc. A/51/10 (1996); see also id. at cmt. para. 10 ("The said clause states that the characterization, or the absence of characterization, of a particular type of behaviour as criminal under national law has no effect on the characterization of that type of behaviour as criminal under international law. It is conceivable that a particular type of behaviour characterized as a crime against the peace and security of mankind in part two might not be prohibited or might even be imposed by national law."). 
that act would be criminal even if every state in the world considered it legal, because rules of international law generally ${ }^{61}$ apply to all states equally:

The notion of international law itself and of an international community under the rule of law is based on the assumption-which, upon analysis, is a statement of fact-that there exist rules and principles of international law of universal validity binding upon all subjects of international law, whether States or not, regardless of their race, religion, geographical situation, political creed, or degree of civilization. ${ }^{62}$

The idea of direct criminalization is seductive: it would be nice to believe that acts like genocide would be universally criminal even if one, 10, or 196 states considered them legal. But how do we know that international crimes are directly criminalized by international law-as opposed to international law obligating all states to incorporate those crimes into their domestic law?

There are two possible methodological bases for the DCT: naturalism and positivism. Neither, unfortunately, is capable of justifying the idea of direct criminalization.

\section{A. Naturalism}

According to Van Schaack, the natural-law tradition "is particularly cogent in ICL," because the field has generally evolved as a reaction to the commission of mass atrocity, "when a desire to ensure the confluence of law and morality is likely to be at its strongest." ${ }^{63}$ The ILC's post-Nuremberg identification of acts that should be considered "crimes against the peace and security of mankind" is a case in point. As Abi-Saab has noted:

The Rapporteur spécial and the ILC were bold enough to admit that here we have to refer to extra-legal factors; that ... . [ [t]hey can only be identified by reference to the feeling and conviction of the international community that certain interests and values are of primordial importance to it, which leads in turn to attaching a

61. The exception-persistent objection—is discussed below.

62. Hersch Lauterpacht, International Law-The General Part, in Collected Papers of Hersch LaUterpacht 1, 113 (Elihu Lauterpacht ed., 1970); see also Robert Y. Jennings, Universal International Law in a Multicultural World, in Liber AmiCorum FOR the RT. HON. LORD WiLberforce 39, 42 (Maarten Bos \& Ian Brownlie eds., 1987) ("Nor can there be any question of an area of the globe where the writ of international law does not run."); Bruno Simma, Universality of International Law from the Perspective of a Practitioner, 20 EUR. J. INT'L L. 265, 267 (2009) ('[T]he 'classic' understanding of our notion, universality of international law, means that there exists on the global scale an international law which is valid for and binding on all states."); North Sea Continental Shelf Cases (Fed. Republic of Ger./ Den.; Fed. Republic of Ger./Neth.), Judgment, 1969 I.C.J. Rep. 39, \63 (Feb. 20) (“[C]ustomary law rules and obligations ... by their very nature, must have equal force for all members of the international community.") [hereinafter North Sea Continental Shelf].

63. Beth Van Schaack, Crimen Sine Lege: Judicial Lawmaking at the Intersection of Law and Morals, 97 Geo. L.J. 119, 157 (2008). 
special type of legal sanction to the norms intended to protect them. ${ }^{64}$

Whatever its merits as an explanation of why states should comply with international law, ${ }^{65}$ naturalism cannot provide a convincing defense of the DCT. To begin with, naturalism is almost by definition incapable of resolving the many disagreements over which acts qualify as international crimes, because it cannot adjudicate between competing views by relying on empirical evidence of what states actually believe ${ }^{66}$ - a limitation that even avowed naturalists acknowledge. ${ }^{67}$ As a result, the naturalist identification of international crimes is either wholly tautological-determining international crimes by reference to the primordial values of the international community, and determining the primordial values of the international community by reference to which acts are internationally criminalized ${ }^{68}$ — or based solely on criteria that are subjective, contestable, and irremediably political. ${ }^{69}$ To take perhaps the most striking example, the ILC's naturalist criterion for an international crime - "an international obligation of essential importance" has been denounced by Green as "highly reminiscent of the Hitlerite concept of the 'fundamental idea of law and sound fundamental popular feeling. ".70 Nor has naturalism in general fared any better. Cryer, for example, has argued that its vagueness and subjectivity "violate the nullum crimen principle"71 and open the door to neo-colonialism-naturalism's "fellow

64. Abi-Saab, supra note 44, at 147.

65. See generally Stephen Hall, The Persistent Spectre: Natural. Law, International Order and the Limits of Legal Positivism, 12 EUR. J. INT'L L. 269-307 (2001) (arguing that naturalism provides the only coherent explanation of why international law is obligatory).

66. See, e.g., Jörg Kammerhofer, Uncertainty in the Formal Sources of International Law: Customary International Law and Some of Its Problems, 15 Eur. J. INT'L L. 523, 543 (2004) ("While the result of the deduction might or might not correspond to positive norms, a pure deduction will not establish any signs for human-willed activity and thus this approach cannot give much insight into a positive legal order like international law."); Martti Koskenniemi, From Apology to Utopia 308 (2006) ("Naturalism needs positivism to manifest its content in an objective fashion. "Justice", "common interest" or "reasonableness" seem to be arguable in a tangible way only by linking them to what States have thought them to mean-to what they have consented to.").

67. See, e.g., Hall, supra note 65, at 306 ("The natural law is not a vehicle ... for providing detailed and prescriptive answers to the numerous problems of international life. It provides us merely with a coherent framework within which we are free to fashion just solutions within very broadly set limits.").

68. See O'KeEFe, supra note 2, at 59-60.

69. See, e.g., Koskenniemi, supra note 56, at 1947 (noting that naturalist argument is "not open to a modern lawyer or court, much less an international court, established for the settlement of disputes between varying cultures, varying traditions, and varying conceptions of reason and justice," because "[s]uch conceptions seem to be historically and contextually conditioned, so that imposing them on a nonconsenting state seems both political and unjustifiable as such").

70. Leslie C. Green, New Trends in International Criminal Law, 11 Isr. Y.B. Hum. RTs. 9, 29 (1981); see also Manfred Mohr, The ILC's Distinction Between "International Crimes" and "International Delicts" and its Implications, in United Nations Codification of State Responsibility 123 (Marina Spinedi \& Bruno Simma eds., 1987) (criticizing the criterion for leaving "too much room for (conflicting) interpretation and subjectivism"); Jean Allain, A Patchwork of Norms: A Commentary on the 1996 Draft Code Against the Peace and Security of Mankind, 8 EUR. J. INT'L L. 100, 102 (1997) (describing the criterion as "pure innovation").

71. Cryer, Doctrinal, supra note 8, at 127. 
traveler." 72 Relying on naturalism to determine the central concept of ICL-what qualifies as an international crime-is thus antithetical to ICL's legitimacy. ${ }^{73}$

Even more fundamentally, naturalism is incapable of explaining why acts that qualify as international crimes are directly criminalized by international law-the defining characteristic of the DCT. Even if we accept that international crimes are acts that contravene "principles of justice which [have] a universal and eternal validity," there is no a priori reason why their universal criminality has to be ensured by direct criminalization, instead of by a universal obligation on states not to tolerate the offending conduct. ${ }^{74}$ Indeed, as we will see, Grotius's naturalist understanding of international criminality depends precisely on the existence of such an obligation.

\section{B. Positivism}

At first glance, positivism provides a much more plausible basis for the DCT. The fundamental problem with naturalism is its indeterminacy-its lack of a concrete method for determining the specific rules of international law. Positivism may be more art than science, ${ }^{75}$ but it at least has the merit of deriving international legal rules inductively, on the basis of how states act, instead of deductively, on the basis of supposedly universal values. So just as there is no a priori reason why naturalism can establish the existence of direct criminalization by international law, there is no a priori reason why positivism cannot. ${ }^{76}$ Because "international law is what states make it, and they can make it bind individuals directly," 77 the only relevant question is whether the DCT is supported by the formal sources of international law.

As noted earlier, every international tribunal has claimed a strict fidelity to positivism-as have most ICL scholars, ${ }^{78}$ even those, such as Bassiouni, ${ }^{79}$

72. Id. at 113 .

73. Id.

74. Akehurst, supra note 12, at 15. See, e.g., Win-Chiat Lee, International Crimes and Universal Jurisdiction, in International Criminal Law And Philosophy 15, 20 (Larry May \& Zachary Hoskins eds., 2010) ("More important, even if we do invoke natural law, the claim that certain acts are simply wrong by nature and therefore ought to be suppressed universally does not, by itself, explain the idea that these acts should be criminalized internationally as a matter of principle. This claim could very well lead to the conclusion that each and every state has a duty to criminalize these acts within their municipal law").

75. See generally David Kennedy, The Sources of International Law, 2 Am. UnIV. INT'L L. Rev. 1 (1987).

76. See Georg Schwarzenberger, The Problem of an International Criminal Law, 3 Curr. Legal Probs. 263, 276 (1950) ("Whether any subjects or objects of international law are the addressees of rules of international criminal law depends on a very simple criterion: the evidence introduced by those who assert the existence of an international criminal law.").

77. O'KeEFe, supra note 2, at 83.

78. See, e.g., Farhad Malekian, I International Criminal Law 23 (1991) ("[T]he only acceptable method for identifying the existence of an international crime is the adoption of certain international rules by a custom, by any norm or by a conventional rule in the practice of nations through consensus.").

79. M. Cherif Bassiouni, The Penal Characteristics of Conventional International Criminal Law, 15 CASE W. RES. J. INT'L L. 27, 28 (1983) ("The only basis which now exists [for international crimes] is empirical or experiential; conventional and customary international law implicitly or explicitly establish that a given act is part of international criminal law."). 
who promote a particularly expansive version of ICL. It is thus surprising that, with the exception of a moderately-skeptical O'Keefe, ${ }^{80}$ no scholar has attempted a serious positivist defense of direct criminalization. Instead, they have generally focused on using positivism to defend the idea of individual criminal responsibility under international law. As discussed above, however, there is no necessary connection between the international criminality of a particular act and its direct criminalization. So the question remains: is the idea of direct criminalization positivistically defensible? Or does the DCT require recourse to naturalism, with all its attendant problems?

To begin with, it is important to recognize that we are really asking whether the direct criminalization of international crimes qualifies as a rule of general international law. Substantive obligations contained in multilateral treaties apply only to state parties; they do not apply to non-parties. So although a treaty that affirms direct criminalization of a particular act could contribute to the creation of a parallel customary rule that applied to all states equally, ${ }^{81}$ as a matter of conventional law only a universally ratified treaty affirming direct criminalization could satisfy the DCT's universality requirement. To date, no such treaty exists. ${ }^{82}$

It is an open question, however, whether the DCT can be satisfied by an "ordinary" rule of custom that establishes the direct criminalization of international crimes. The problem is the doctrine of persistent objection, which permits a state to "opt out" of a rule that is crystallizing but has not yet achieved customary status. ${ }^{83}$ If persistent objection is possible in ICL, states were free to persistently object to the direct criminalization of the core international crimes ${ }^{84}$ and remain free to persistently object to the direct criminalization of new ones. The possibility of persistent objection, however, means that the universal criminality of international crimes can, in fact, be limited by domestic law-which is precisely what the DCT prohibits.

Proponents of the DCT are thus faced with a choice: either reject the idea of persistent objection or argue that the direct criminalization of international crimes is jus cogens, making persistent objection to direct criminalization impossible. ${ }^{85}$ The first option is obviously more desirable, because it is far more difficult to prove the existence of a jus cogens norm than it is to

80. See O'KeEFe, supra note 2 , at 73 .

81. See Brownlie's Principles of Public International Law 31 (Ian Brownlie \& James Crawford eds., 8th ed. 2012).

82. As discussed below, the Geneva Conventions-the only universally-ratified treaties that affect ICL-function as suppression conventions.

83. See, e.g., ILA Custom Report, supra note 15, at 27.

84. It is an open question whether any state did, with the possible exception of aggression. See Kenneth S. Gallant, Jurisdiction to Adjudicate and Jurisdiction to Prescribe in International Criminal Courts, 48 VILL. L. Rev. 763, 834 (2003) ("In general, there has not been persistent objection by States to the creation of customary norms forbidding genocide, crimes against humanity and war crimes").

85. See, e.g., ILA Custom Report, supra note 15, at 10 (rejecting persistent objection to jus cogens norms); Patrick Dumberry, Incoherent and Ineffective: The Concept of Persistent Objector Revisited, 59 ICLQ 779, 798-99 (2010) (same). 
prove an ordinary customary rule. ${ }^{86}$ The problem is that, despite a few scholarly dissenters, ${ }^{87}$ the possibility of persistent objection is generally accepted. Crawford, for example, states that " $[\mathrm{w}]$ hatever the theoretical underpinnings of the persistent objector principle, it is recognized by international tribunals, and in the practice of states." 88 Similarly, the International Law Association's Final Report on Custom acknowledges that " $[\mathrm{i}] \mathrm{f}$ whilst a practice is developing into a rule of general law, a State persistently and openly dissents from the rule, it will not be bound by it." 89

Because of persistent objection, DCT proponents likely need to argue that the direct criminalization of international crimes is jus cogens. To date, no ICL scholar has specifically made that claim - although many scholars, ${ }^{90}$ as well as the ILC's Working Group on the Obligation to Extradite or Prosecute, ${ }^{91}$ take the position that the international crimes are jus cogens themselves. The two arguments, however, are not coterminous: the obligation to avoid committing war crimes, crimes against humanity, and genocide might rise to the level of universal international law without international law directly criminalizing those acts. It is equally possible-and more positivistically defensible, as explained in the next Part-that the jus cogens status of the international crimes could impose an obligation on all states to incorporate international crimes into their domestic law. That does not mean, of course, that direct criminalization cannot be jus cogens. But it does mean that whether direct criminalization is jus cogens is a different inquiry than whether international crimes are, requiring different state practice and opinio juris. ${ }^{92}$

It is exceedingly unlikely that state practice and opinio juris establish that direct criminalization of international crimes is a jus cogens norm. In fact, as

86. See, e.g., Erika De Wet, Jus Cogens and Obligations Erga Omnes, in The Oxford Handbook oF International Human Rights Law 542 (Dinah Shelton ed., 2013) (noting that Art. 53 VCLT's reference to "the international community as a whole" implies that "a particular norm is first recognized as customary international law, whereafter the international community of states as a whole further agrees that it is a norm from which no derogation is permitted. The international community of states as a whole would therefore subject a peremptory norm to 'double acceptance').

87. See, e.g., Dumberry, supra note 85 , at 780 ("Our survey will show that there is only very weak judicial recognition of the theory of persistent objector and that there is no actual State practice supporting it.").

88. Brownlie's Public International Law, supra note 81, at 28.

89. ILA Custom Report, supra note 15, at 27.

90. See, e.g., Allain Pellet, Can a State Commit a Crime? Definitely, Yes!, 4 ILSA J. INT'L \& Comp. L. 315, 318 (1997-1998) ("I . . . urge that it would be easier and more convenient to define an international crime as a breach of a norm of jus cogens."); MAY, supra note 47, at 25 ("Jus cogens norms-literally the laws or norms that are known and binding throughout humanity-form the clearest basis for identifying distinctly international crimes as violations of international law.").

91. Kriangsak Kittichaisaree, 65th Session of the International Law Commission, Informal Working Paper of the Working Group on the Obligation to Extradite or Prosecute, I 189, UN Doc. ILC(LXV)/WG/OEP/ INFORMAL/1 (April 5, 2013) (noting that "the core crimes under international law [are] proscribed by jus cogens") [hereinafter "ILC Extradite or Prosecute Paper"].

92. In a similar fashion, the ILC insists that it is not possible to assume that states have a customary obligation to extradite or prosecute individuals suspected of international crimes simply because the crimes themselves are jus cogens. See generally id. 
the following discussion shows, direct criminalization does not even qualify as an ordinary rule of custom. "To determine the existence and content of a rule of customary international law, it is necessary to ascertain whether there is a general practice that is accepted as law (opinio juris)." 93 To qualify as "general," state practice "must be sufficiently widespread and representative, as well as consistent." 94 Such practice normally accretes slowly, but there is no minimum amount of time required. ${ }^{95}$ Many different kinds of action qualify as state practice, including both physical acts and verbal acts. ${ }^{96}$ No matter what form practice takes, however, the requirement of opinio juris "means that the practice in question must be undertaken with a sense of legal right or obligation." 97

With those basic principles in mind, this Article turns to five types of evidence that could support the customary status of direct criminalization.

\title{
1. Ratification of Multilateral Treaties
}

The first potential source of state practice and opinio juris is the ratification of multilateral treaties that affirm the direct criminalization of certain acts. A treaty can contribute to the formation of a customary rule, as long as it is widely ratified and intended to have a law-making effect:

\begin{abstract}
"[L]aw-making treaties" . . are intended to have an effect generally, not restrictively, and they are to be contrasted with those treaties which merely regulate limited issues between a few states. Law-making treaties are those agreements whereby states elaborate their perception of international law upon any given topic or establish new rules which are to guide them for the future in their international conduct. Such lawmaking treaties, of necessity, require the participation of a large number of states to emphasise this effect, and may produce rules that will bind all. They constitute normative treaties, agreements that prescribe rules of conduct to be followed. ${ }^{98}$
\end{abstract}

93. ILC Draft Conclusions, supra note 15 , at 1.

94. Id. at 3; see also ILA Custom Report, supra note 15, at 20.

95. ILC Draft Conclusions, supra note 15, at 3; see also ILA Custom Report, supra note 15, at 20.

96. ILC Draft Conclusions, supra note 15, at 2; see also ILA Custom Report, supra note 15, at 14.

97. ILC Draft Conclusions, supra note 15, at 3.

98. Malcolm N. Shaw, International Law 95 (6th ed. 2008); see also Brownlie's Public InTERNATIONAL LAW, supra note 81, at 31 ("Although treaties are as such binding only on the parties, the number of parties, the explicit acceptance of these rules by states generally and, in some cases, the declaratory character of the provisions combine to produce a powerful law-creating effect."); Robert Cryer, Of Custom, Treaties, Scholars, and the Gavel: The Influence of International Criminal Tribunals on the ICRC Customary Law Study, 11 J. CONFL. \& SEC. L. 239, 244 (2006) (noting, with regard to multilateral treaties, that "a very widely ratified treaty has a considerable 'pull' towards acceptance, as there is a feeling that if a treaty is very broadly ratified, it represents the general expectations of those states"); R.R. Baxter, Multilateral Treaties as Evidence of Customary International Law, 41 BRIT. Y.B. INT'L L. 275, 278 (1965-1966) ("Having regard to the limited amount of State practice which is generally regarded as sufficient to establish the existence of a rule in customary international law, a treaty to which a substantial number of States are parties must be counted as extremely powerful evidence of the law."). 
Indeed, the ICJ has suggested that a law-making treaty with "very widespread and representative participation," particularly by specially-affected states, might by itself be sufficient to create customary international law. ${ }^{99}$ It is not surprising, therefore, that scholars have pointed to multilateral treaties as evidence that international crimes are prohibited by customary as well as by conventional law. ${ }^{100}$

Even if multilateral treaties can contribute to the formation of custom or create custom by themselves - the latter idea being very controversial, having been generally rejected by the International Law Association (ILA) ${ }^{101}$ ICL treaties provide very little support for the idea that the core international crimes are directly criminalized by international law. The following analysis begins by discussing international treaties and conventions that address specific core international crimes. It then examines the two treaties that established international criminal tribunals: the London Charter and the Rome Statute.

\section{a. War Crimes}

War-crimes treaties provide almost no support for the DCT. The universally-ratified Geneva Conventions do not declare that war crimes are "crimes under international law"; they do not even qualify grave breaches as "crimes of a truly international character." 102 They are simply suppression conventions that require states to domestically criminalize the grave breaches. ${ }^{103}$ The First Additional Protocol describes grave breaches as "war crimes," 104 but says nothing about direct criminalization, choosing instead to apply the state-centered suppression regime established by the Geneva Conventions. ${ }^{105}$ And the Second Additional Protocol does not even contemplate criminal responsibility for violations of IHL in non-international armed conflict. ${ }^{106}$

The only multilateral war-crimes treaties that potentially support the DCT, therefore, are the Convention on the Non-Applicability of Statutory Limitations to War Crimes and Crimes Against Humanity ${ }^{107}$ and the Rome

99. See North Sea Continental Shelf, supra note 62, at 43.

100. Bassiouni, Penal Characteristics, supra note 79 , at 29 (" $[\mathrm{A}] \mathrm{n}$ international crime is any conduct which is designated as a crime in a multilateral convention recognized by a significant number of states.").

101. See ILA Custom Report, supra note 15, at 54 ("[A] single plurilateral or bilateral treaty cannot instantly create general customary law 'of its own impact', and it seems improbable that even a series of such treaties will produce such an effect, save in (at most) the rarest of circumstances.").

102. See Simma \& Paulus, supra note 10, at 311.

103. Convention Relative to the Protection of Civilian Persons in Time of War (Geneva Convention IV), art. 146, Aug. 12, 1949, 6 UST 3516, 75 U.N.T.S. 287 (Aug. 12, 1949).

104. Protocol Additional to the Geneva Conventions of 12 August 1949, and Relating to the Protection of Victims of Non-International Armed Conflicts (Protocol I), art. 85(5), Jun. 8, 1977, 1125 U.N.T.S. 609 (June 8, 1977).

105. Id., art. 86 .

106. See Simma \& Paulus, supra note 10, at 311.

107. Convention on the Non-Applicability of Statutory Limitations to War Crimes and Crimes Against Humanity, Nov. 26, 1968, 754 U.N.T.S. 73. 
Statute. ${ }^{108}$ The Rome Statute is addressed separately below. As for the Statute of Limitations Convention, although it deems war crimes to be "among the gravest crimes in international law," 109 it does not specifically affirm their direct criminalization - which it does for crimes against humanity and genocide.

\section{b. Crimes Against Humanity}

Other than the London Charter and the Rome Statute, only two treaties address crimes against humanity: the Statute of Limitations Convention and the International Convention on the Suppression and Punishment of the Crime of Apartheid. ${ }^{110}$ The text of the Statute of Limitations Convention clearly supports the DCT, because it specifically prohibits applying statutes of limitations to crimes against humanity (and genocide) "even if such acts do not constitute a violation of the domestic law of the country in which they were committed." ${ }^{111}$ The Convention, however, has not proven popular with states: despite having been open for signature for nearly five decades, only 55 states have ratified it. ${ }^{112}$ The Convention thus provides little support for a customary rule of direct criminalization.

The Apartheid Convention, which deems apartheid a crime against humanity, ${ }^{113}$ also provides little support for the DCT. Although the Convention provides that there is "international criminal responsibility" for acts of apartheid, ${ }^{114}$ the Convention functions as a suppression convention, ${ }^{115}$ with Article IV requiring state parties to criminalize apartheid domestically and exercise universal jurisdiction over the crime. ${ }^{116}$ Moreover, even if the Apartheid Convention did support the DCT, it has been ratified by only $55 \%$ of the world's states-109-and those ratifications are anything but "widespread" and "representative," given that "no western power has accepted it . . . [and] among the 'Great Powers' the Soviet Union is the only one to have done so." 117

108. The London Charter deemed war crimes "crimes coming within the jurisdiction of the Tribunal." Charter of the International Military Tribunal - Annex to the Agreement for the Prosecution and Punishment of the Major War Criminals of the European Axis, art. 6(c), Aug. 8, 1945, 58 Stat. 1544, 82 U.N.T.S. 280. The Charter is discussed below.

109. Convention on the Non-Applicability of Statutory Limitations, pmbl., para. 5, Nov. 26, 1968, 754 U.N.T.S. 73.

110. International Convention on the Suppression and Punishment of the Crime of Apartheid, Jul. 18, 1976, 1015 U.N.T.S. 243.

111. Statute of Limitations Convention, supra note 109, art. 1(b).

112. International Committee of the Red Cross, Treaties, States Parties and Commentaries, Convention on the Non-Applicability of Statutory Limitations to War Crimes and Crimes Against Humanity, https://www.icrc.org/ihl/INTRO/435?OpenDocument.

113. Apartheid Convention, supra note 110, art. 1.

114. Id., art. 3 .

115. See, e.g., Gaeta, supra note 49 , at 64.

116. Apartheid Convention, supra note 110, art. 4.

117. L. C. Green, International Crimes and the Legal Process, 29 INT'L L. CoMP. Q. 567, 579 (1980). 


\section{c. Genocide}

At first glance, the Genocide Convention appears to provide strong support for the DCT. The Convention specifically refers to genocide as "a crime under international law," 118 which indicates that it has a law-making quality. ${ }^{119}$ Moreover, the Genocide Convention has gained far more international acceptance than the Statute of Limitations Convention or the Apartheid Convention, with 147 states parties- $76 \%$ of the world's states. ${ }^{120}$

Looks, however, can be deceiving. It is ahistorical to assume that the Genocide Convention's reference to genocide as a "crime under international law" was designed to affirm direct criminalization. On the contrary, as Kunz noted in 1949, the drafters had no such intention:

The Convention is entirely different from the law of the Nuremberg Trial and does not create at all an international criminal law nor international criminal courts ... . The Convention does not make individuals subjects of international law, nor of international duties or international rights; it is, in this respect, a thoroughly old-fashioned, traditional treaty .... Under Article I it is the states which recognize that genocide is a crime under international law which they-not international law-undertake to prevent and punish. ${ }^{121}$

Put more simply, the Genocide Convention was a forerunner of the modern suppression convention, relying on the goodwill of states to achieve the universal criminalization of genocide. ${ }^{122}$ Indeed, although this has also been generally forgotten, even the Convention's much-hallowed reference to the possibility of an "international penal tribunal" emphasized that the authority of any such tribunal would be based on states freely accepting its jurisdiction. ${ }^{123}$ The Genocide Convention's widespread ratification thus does not help establish the customary status of direct criminalization. Instead, it contributes to a customary obligation on states to criminalize genocide domestically-the hallmark of the NCT.

118. Convention on the Prevention and Punishment of the Crime of Genocide, art. 1, Dec. 9, 1948, 78 U.N.T.S. 277.

119. Crawford specifically cites the Genocide Convention as an example of a law-making treaty. See Brownlie's Public International Law, supra note 81, at 31.

120. For a list of states that have ratified the Genocide Convention, see U.N., Status of Convention on the Prevention and Punishment of the Crime of Genocide, https://treaties.un.org/Pages/ ViewDetails.aspx?src=IND\&mtdsg_no=IV-1\&chapter $=4 \&$ clang $=$ _en.

121. Josef L. Kunz, The Genocide Convention, 43 Am. J. InT'L L. 732, 744 (1949).

122. Gaeta, supra note 49, at 67 ("This Convention. . applied the traditional scheme of repression, by requesting contracting states to criminalize genocide within its legal orders.").

123. Genocide Convention, supra note 118, art. 6 ("Persons charged with genocide or any of the other acts enumerated in article III shall be tried. . .by such international penal tribunal as may have jurisdiction with respect to those Contracting Parties which shall have accepted its jurisdiction.”). 


\section{d. Aggression}

The London Charter and the Rome Statute are the only treaties that address the crime of aggression. They are discussed below.

\section{e. The London Charter}

There is one reference to direct criminalization in the London Charter: Art. 6(c), which deemed crimes against humanity punishable "whether or not in violation of the domestic law of the country where perpetrated." 124 The ILC repeated that expression almost verbatim in Art. 1(2) of the 1996 Draft Code, which explicitly affirms the DCT. ${ }^{125}$

The London Charter supports the DCT, however, only if the drafters either believed that the Charter reflected customary international law or at least intended the Charter to establish new rules that would subsequently bind all states. With regard to the first interpretation, the Charter itself is equivocal: although Art 6(c) refers to the irrelevance of domestic law, the text of the Charter does not refer even once to "international law" and describes war crimes, crimes against humanity, and aggression as "crimes coming within the jurisdiction of the Tribunal," not as "crimes under international law." 126 The drafting history also fails to provide a definitive answer, although it is difficult to argue that all four Allies believed that the Charter was an expression of customary international law as it stood prior to the war. During the London Conference, for example, Professor Andre Gros, a member of the French delegation, objected that the crimes contained in the Charter were nothing more than the "creation of four people who are just four individuals," because "[t] those acts have been known for years before and have not been declared criminal violations of international law." 127 Sir David Maxwell Fyfe, the British delegate-and subsequently the British prosecutor at the IMT-later responded that "[w]hat we want to abolish at the trial is a discussion as to whether the acts are violations of international law or not. We declare what international law is . . there won't be any discussion of whether it is international law or not." 128

Despite Fyfe's reference to the Allies enunciating international law, the second interpretation of the Charter-that it declared international law but did not necessarily reflect it-is also questionable. Most notably, the UN Secretary-General rejected that position in his 1949 report on the IMT. In his view, because "[t] the London Agreement and the Charter annexed to it provide for the trial by a special tribunal (or eventually several special tribunals) of a group of well-defined cases," they appear to be "a lex in casu to be

124. London Charter, supra note 108, art. 6(c).

125. Supra note 60.

126. Id.

127. Matthew Lippman, Nuremberg: Forty-Five Years Later, in PerspeCtives on the Nuremberg Trial 510 (Guénaël Mettraux ed., 2008).

128. Id. 
applied by an ad hoc tribunal to a special case or group of cases." 129 Scholars writing at the time also generally took the position that the Charter was law solely for the Nazi defendants. Kunz, for example, described the Charter as "only a lex specialis against a named group of men in the service of a conquered enemy." ${ }^{30}$ Kelsen agreed, writing that "[t the source of law is the London Agreement; and it is a source of law only and exclusively for the International Military Tribunal established by this Agreement." 131 As a result, even if the Charter affirmed direct criminalization, it provides neither state practice nor opinio juris in favor of the DCT. ${ }^{132}$

The Tribunal itself, of course, viewed the London Charter quite differently-as both reflecting and declaring international law. "The Charter is not an arbitrary exercise of power on the part of the victorious nations," the judges wrote, but "the expression of International Law existing at the time of its creation; and to that extent is itself a contribution to International Law." 133 The judgment also explicitly affirmed the idea of direct criminalization- "individuals have international duties which transcend the national obligations of obedience imposed by the individual state."

The Nuremberg judgment nevertheless provides little support for the DCT. To begin with, the judgment itself represents neither state practice nor opinio juris in favor of direct criminalization, because the decisions of international tribunals are simply subsidiary means for determining the primary rules of international law. ${ }^{134}$ Moreover, and more fundamentally, the judgment is a particularly unconvincing subsidiary means. Not only was the IMT almost certainly wrong concerning the legal status of the London Charter-for the reasons discussed above-it is difficult to argue that international law directly criminalized war crimes, crimes against humanity, and acts of aggression prior to the IMT itself. ${ }^{135}$ As O'Keefe charitably puts it, the Tribunal's claim that "individuals can be punished for violations of in-

129. The Charter and Judgment of the Nürnberg Tribunal: History and Analysis, Memorandum Submitted by the Secretary-General 37, UN Doc. A/CN.4/5 (1949).

130. Kunz, supra note 121, at 742 .

131. Hans Kelsen, Will the Judgment in the Nuremberg Trial Constitute a Precedent in International Law?, in Mettraux, supra note 127, at 282.

132. See Kress, ICL, supra note 10, at 23 ("From an institutional perspective, it is difficult to portray these tribunals as organs of the international community and as a first instance of a direct enforcement of international criminal law.”).

133. IMT Judgment, supra note 57, at 444; see also UNSG Nuremberg Report, supra note 129, at 38 ("The Court thus considerably widened the scope of the Charter and, at the same time, of its own findings. It affirmed the validity of the Charter not only as a lex in casu, as the law of the case which it had been set to judge, but also as an authoritative expression of general international law.").

134. See iCRC, I Customary International Humanitarian Law: Rules xxxiv (Jean-Marie Henckaerts \& Louise Doswald-Beck eds., 2005); ILC Draft Conclusions, supra note 15, at 4; cf. Georg Schwarzenberger, The Judgment of Nuremberg, in METTRAux, supra note 127, at 176 ("The Judgment is a contribution to international law to the extent to which . . the Tribunal has made itself an instrument for declaring pre-existing law.").

135. See, e.g., O'KeEfE, supra note 2, at 73 ("[S]erious doubts existed as to whether the concepts of crimes against humanity and crimes against peace really did reflect customary international law as it stood at the time of commission."). 
ternational law masked a lack of clarity as to the precise juridical basis for this statement." ${ }^{136}$

\section{f. The Rome Statute}

Although the precise relationship between the Rome Statute and customary international law is much debated, ${ }^{137}$ nearly all scholars agree that the definitions of crimes were generally intended to reflect custom. ${ }^{138}$ There is no question, therefore, that the Rome Statute's 125 ratifications help confirm the customary status of war crimes, crimes against humanity, genocide, and (perhaps) aggression.

The Rome Statute provides no support, however, for the idea that the core international crimes are directly criminalized by international law. The text of the treaty does not affirm direct criminalization; it does not even use the expression "crime under international law." ${ }^{139}$ More importantly, the Rome Statute consistently foregrounds the importance of domestic criminalization of international crimes. The Preamble, for example, recalls "that it is the duty of every State to exercise its criminal jurisdiction over those responsible for international crimes" 140 and emphasizes that the ICC "shall be complementary to national criminal jurisdictions." 141 More importantly, because the Court is based on the delegated jurisdiction of its member states, ${ }^{142}$ its ability to prosecute an international crime always depends-at least in the absence of a Security Council referral, whose legislative authority is discussed below-on the consent of either the territorial state or the state of active nationality. ${ }^{143}$ Such dependence is the antithesis of the DCT, which is predicated on the idea that international crimes can be prosecuted even in the absence of state consent.

136. Id.

137. See Leila Sadat, Custom, Codification and Some Thoughts About the Relationship Between the Two: Article 10 of the ICC Statute, 49 DePaul L. Rev. 909, 911-17 (1999-2000).

138. See, e.g., Philip Kirsch, Foreword, in Knut Dormann, Elements of War Crimes under the Rome Statute of the International Criminal Court xiii (2003) (noting that there was 'general agreement that the definitions of crimes in the ICC Statute were to reflect existing customary international law, and not to create new law"); see also Darryl Robinson \& Herman von Hebel, War Crimes in Internal Conflicts: Art. 8 of the ICC Statute, 2 Y.B. OF INT'L Human. L. 193, 194 (1999) (same).

139. Instead, the Rome Statute describes the crimes within the jurisdiction of the Court as the "most serious crimes of concern to the international community as a whole." See Rome Statute, supra note 35, Preamble, para. 4.

140. Id., para. 6 .

141. Id., para. 10 .

142. See, e.g., Olympia Bekou \& Robert Cryer, The International Criminal Court and Universal Jurisdiction: A Close Encounter?, 56 ICLQ 49, 50-51 (2009) ("The ICC operates on the basis of delegated jurisdiction from its States parties."); Hans Peter Kaul \& Claus Kress, Jurisdiction and Cooperation in the Statute of the International Criminal Court: Principles and Compromises, 2 Y.B. InT'L Human. L. 143, 145 (1999) (noting that the Rome Statute is based on "the very simple idea that states must be entitled to do collectively what they have the power to do individually").

143. Expressed, of course, by the decision to ratify or accede to the Rome Statute - automatic jurisdiction. 


\section{Domestic Incorporation and National Prosecution}

A second potential source of evidence for the DCT would be the incorporation of international crimes into domestic law and the prosecution of international crimes in national courts. Both count as state practice for purposes of establishing customary international law. ${ }^{144}$ Many states domestically criminalize international crimes-as of 2011, more than 140 criminalized at least one war crime, more than 90 criminalized at least one crime against humanity, and more than 115 criminalized genocide. ${ }^{145} \mathrm{Na}-$ tional prosecutions of international crimes have also become increasingly commonplace.

Domestic legislation and national prosecutions clearly help establish the customary status of individual criminal responsibility for international crimes. ${ }^{146}$ But it is difficult to see how they could support the idea of direct criminalization. States overwhelmingly criminalize and prosecute international crimes because they have ratified a treaty (most often, the Geneva Conventions or the Genocide Convention) that requires them to do so. Such indirect enforcement of international criminal law may well contribute to a customary obligation on all states to criminalize and prosecute international crimes, but almost by definition it cannot contribute to a customary rule that says certain acts are directly criminalized by international law regardless of domestic criminalization. Domestic criminalization and prosecution would thus favor the NCT instead of the DCT, given that the hallmark of the NCT is the existence of a universal obligation to criminalize.

It is possible, of course, that some states criminalize and prosecute international crimes because of a perceived need to enforce international law's direct criminalization of certain acts. Crimes against humanity would be the most promising candidate, given that at least 90 states have incorporated at least one crime against humanity into their domestic criminal law ${ }^{147}$ even though only apartheid is addressed by a suppression convention. Other explanations, however, are equally if not more likely. Such incorporation could reflect the growing belief that customary international law imposes an obligation on states to either extradite or punish (aut dedere aut judicare) individuals suspected of committing core international crimes $^{148}$ —an explanation

144. See, e.g., ILA, Custom Report, supra note 15, at 18.

145. See Amnesty International, supra note 16, at 12-13.

146. See, e.g., Simma \& Paulus, supra note 10, at 309 ("To anchor individual responsibility for genocide in customary law, there must be practice and opinio juris. International practice on the prosecution of perpetrators can be found in both domestic and international trials of offenders.").

147. Amnesty International, supra note 16 , at 13.

148. See, e.g., Christian J. Tams, Do Serious Breaches Give Rise to Any Specific Obligations of the Responsible State?, 13 EUR. J. INT'L L. 1161, 1174 (2002) (arguing, with regard to core international crimes, that "recent developments in international law would indeed point towards the growing acceptance of an obligation to prosecute"); cf. ILC Extradite or Prosecute Paper, supra note 91, \ 189 (concluding that "the obligation aut dedere aut judicare has crystallized or at least is in the process of crystallizing into a rule of customary international law," especially "in the case of core crimes under international law proscribed by jus cogens"). 
that favors the NCT over the DCT. Or it could simply be a way for states to ensure that their nationals are never prosecuted by the ICC. Van Steenberghe identifies five states-Argentina, Panama, Peru, Portugal, and Uruguay-that have incorporated international crimes for precisely that reason, ${ }^{149}$ and the number is likely much higher, given how many states did not incorporate international crimes until they ratified the Rome Statute. ${ }^{150}$

In any case, the ambiguity inherent in domestic incorporation means that incorporation does not support direct criminalization. As the ILA has pointed out, ambiguous conduct counts as state practice only if it is accompanied by unambiguous opinio juris, whether express or implied. ${ }^{151}$

\section{General Assembly Resolutions}

A third potential source of evidence for the DCT would be resolutions adopted by the UN General Assembly. Resolutions of international organizations qualify as both state practice ${ }^{152}$ and opinio juris, ${ }^{153}$ and "[w]here the vast majority of states consistently vote for resolutions and declarations on a topic. . . a binding rule may very well emerge provided that the requisite opinio juris can be proved." 154 It is an open question, however, whether General Assembly resolutions are capable of establishing new rules of customary international law even without accompanying state practice-socalled "instant custom." The ILA takes the position that "[r]esolutions accepted unanimously or almost unanimously, and which evince a clear intention on the part of their supporters to lay down a rule of international law, are capable, very exceptionally, of creating general customary law by the mere fact of their adoption." 155 Some scholars agree, most notably Bin Cheng. ${ }^{156}$ The ILC, however, rejects the idea of instant custom, insisting that " $[\mathrm{a}]$ resolution adopted by an international organization or at an intergovernmental conference cannot, of itself, create a rule of customary international law." 157 Many scholars are also skeptical ${ }^{158}$ — and the idea of instant

149. Raphael van Steenberghe, The Obligation to Extradite or Prosecute: Clarifying its Nature, $9 \mathrm{~J}$. INT'L Crim. Just. 1089, 1097 (2011).

150. Bangladesh, Burkina-Faso, Comoros, Congo, Cyprus, Latvia, Mali, Malta, Mexico, Netherlands, Republic of Korea, Samoa, South Africa, Spain. See AmNeSty InTERnAtionAl, supra note 16, at 29-106. Some of those states might have incorporated international crimes because they believe - wrongly - that the Rome Statute requires incorporation. Samoa appears to be in that category. See Appendix.

151. ILA Custom Report, supra note 15 , at 38.

152. See, e.g., ILC Draft Conclusions, supra note 15, at 2; ILA Custom Report, supra note 15, at 19.

153. See, e.g., ILC Draft Conclusions, supra note 15, at 3; ILA Custom Report, supra note 15, at 55-56.

154. Shaw, supra note 98, at 115; see also Gideon Boas, Public International Law: ContempoRARy Principles And Perspectives 87 (2012) ("The value of opinio juris in General Assembly resolutions ... depends on the degree of consensus achieved by particular resolutions, as well as the number of times the norm has been reaffirmed in subsequent resolutions.").

155. ILA Custom Report, supra note 15, at 61.

156. Bin Cheng, Studies in International Space Law 138 (1997) ("Not only is it unnecessary that the usage should be prolonged, but there need also be no usage at all in the sense of repeated practice, provided that the opinio juris of the States concerned can be clearly established. Consequently, international customary law has in reality only one constitutive element, the opinio juris.").

157. ILC Draft Conclusions, supra note 15 , at 4. 
custom seems difficult to reconcile with ICJ jurisprudence. ${ }^{159}$ In the Nicaragua case, for example, the Court stated unequivocally that "[t]he mere fact that States declare their recognition of certain rules is not sufficient for the Court to consider these as being part of customary international law."160

Even if we accept instant custom, however, General Assembly resolutions concerning the core international crimes provide little support for the idea of direct criminalization.

a. Res. 95(I)

The most important General Assembly resolution is the unanimously adopted Res. 95(I), which "[a]ffirm[ed] the principles of international law recognized by the Charter of the Nurnberg Tribunal and the judgment of the Tribunal." ${ }^{61}$ Scholars have routinely relied on Res. 95(I) to affirm the customary status of the Nuremberg Principles. Green, for example, claims that, "[b]y virtue of their acceptance" of the Resolution, "the members of the United Nations have accepted that those principles, including that which affirms the criminality of aggressive war, are declaratory of the customary law regarding crimes against the law of armed conflict." ${ }^{62}$ Courts have done likewise, as illustrated by the European Court of Human Rights' statement in Kolk \& Kislyiy v. Estonia that "the universal validity of the principles concerning crimes against humanity was subsequently confirmed by . . . resolution 95 of the United Nations General Assembly . . . ."163

This understanding of Res. 95(I), however, is ahistorical. There is no question that the UN and many states hoped the General Assembly would draft and adopt a resolution that declared the Nuremberg Principles to be part of customary international law; after all, the Secretary-General told the Assembly during the second day of its first session-a mere three weeks after the IMT judgment had been delivered-that it would be of "decisive

158. See, e.g., Akehurst, supra note 12, at 46 ("[T]he very notion of 'custom' implies some time element and 'instant custom' is a contradiction in terms."); Bruno Simma \& Philip Alston, The Sources of International Human Rights Law: Custom, Jus Cogens, and General Principles, 12 AusT. Y.B. INT'L L. 82, 8990 (1988-1989) (describing the idea of instant custom as "new, radical" and representing a "dubious metamorphosis" in the idea of state practice); Stephen M. Schwebel, The Effect of Resolutions of the UN General Assembly on Customary International Law, 73 AM. SOC'y INT'L L. PROC. 301, 302 (1979) (“General Assembly resolutions are neither legislative nor sufficient to create custom, not only because the General Assembly is not authorized to legislate.").

159. See Akehurst, supra note 12, at 46.

160. Military and Paramilitary Activities in and Against Nicaragua (Nicar. v. U.S.), Judgment, 1986 I.C.J. Rep. 14, 97 (June 27).

161. Affirmation of the Principles of International Law Recognised by the Charter of the Nuremberg Tribunal, GA Res. 95(I), UN Doc. A/236 (Dec. 11, 1946).

162. L.C. Green, Is There an International Criminal Law?, 21 AltA. L. Rev. 251, 255 (1983); see also O'KeEfe, supra note 2, at 73 (arguing with regard to the Nuremberg Principles that the adoption of Res. 95(I) "settl[ed], at a formal level, debate over the principles' claims to the status of positive international law"); Bassiouni, Ratione Personae, supra note 5, at 76 (claiming that the Resolution is "considered declarative of customary international law").

163. Kolk $\mathcal{E}$ Kislyiy v. Estonia, Decision as to Admissibility, Eur. Ct. H.R. (2006), http:// hudoc.echr.coe.int/eng? $i=001-72404 \#\{$ “itemid”: [“001-72404”] $\}$. 
significance to have the principles which were implied in the Nurnberg trials . . made a permanent part of the body of international law as quickly as possible." 164 But those hopes were never realized, because states simply could not agree that the Nuremberg Principles should apply to all states equally. Bin Cheng-the same Bin Cheng who is widely considered the progenitor of instant custom-made that point forcefully in 1965:

[I]n order to speak of a law-finding resolution, there must have existed, first of all, the necessary opinio juris communis among Members of the United Nations that what they are enunciating in the resolution represents binding rules of international law. Secondly, the wording of the resolution must not merely identify clearly the contents of the rules in question, but must also unequivocally express this opinio juris communis . . The same cannot, however, be said of the Assembly resolution 95 (I) "affirming" the so-called "principles of international law recognised by "the Charter of the Nuremberg Tribunal"; for there the Assembly deliberately and rather subtly declined to use either the word "reaffirm" as found in the original United States proposal or the word "confirm", thus indicating clearly a lack of consensus among United Nations Members as to the binding character of the Nuremberg principles as rules of general international law. ${ }^{165}$

Bin Cheng's emphasis on the need for clarity concerning the principles declared to represent customary international law is particularly important, because Res. 95(I) only called upon the Committee on Progressive Development (CPD) ${ }^{166}$ to make plans to formulate the Nuremberg Principles; the General Assembly made no attempt to articulate those Principles itself. ${ }^{167}$ Indeed, the Cuban delegate refused to accept the Resolution precisely because "it affirmed the principles of international law without developing them." 168 Res. 95(I) is thus a striking example of a General Assembly resolution that, to quote the ILA, is "so devoid, or almost devoid, of legally definable content" that it cannot meaningfully contribute to the formation of custom. ${ }^{169}$

The Nuremberg Principles fared no better in the CPD. The drafting SubCommittee initially proposed to instruct the ILC to prepare "a draft convention incorporating the principles of international law as recognized by the Statute of the Tribunal of Nurnberg and sanctioned by the judgment of that

164. UNSG Nuremberg Report, supra note 129, at 11.

165. BIn Cheng, supra note 156, at 141.

166. Referred to in Res. 95(I) as the "Committee on the codification of international law." Res. 95(1) supra note 156, I 4.

167. See Res. 95(I), supra note 161, ๆ 2.

168. Quoted in UNSG Nuremberg Report, supra note 129, at 13.

169. ILA Custom Report, supra note 15, at 62. 
Tribunal, in order to give to these principles a binding force for all." ${ }^{170}$ As the Secretary-General noted in his report on the IMT, however, that universalizing language proved too ambitious for most states to accept:

When the Committee considered the report of the drafting SubCommittee, the representative of Yugoslavia moved to delete the words "binding force for all" and replace them by "binding force for the signatory States" on the ground that conventions could only bind the signatory States. The representative of France agreed with the point of view of the Yugoslav representative and suggested to delete the last part of the sentence altogether beginning from the words "in order to," etc. This suggestion was supported by the representative of the Soviet Union and approved by the Committee. ${ }^{171}$

The CPD's position was thus clear: states would be free to accept or reject the Nuremberg Principles (when formulated by the ILC) as they saw fit, because the Principles did not represent customary international law.

b. Res. 96(I)

In contrast to Res. 95(I), Bin Cheng specifically cited Res. 96(I), which affirmed the international criminality of genocide, as an example of a General Assembly resolution capable of creating instant custom. ${ }^{172}$ The Resolution, however, provides no more support for the DCT than the Genocide Convention itself: although Res. 96(I) deemed genocide a "crime under international law," it did not affirm the idea of direct criminalization. ${ }^{173} \mathrm{On}$ the contrary, the Resolution's operative provisions simply invited states "to enact the necessary legislation for the prevention and punishment of this crime" 174 and recommended that "international co-operation be organized between States." 175 Insofar as Res. 96(I) created (instant) custom, then, it created a customary obligation on states to criminalize genocide domestically - the hallmark of the NCT, not the DCT.

170. Report of the Committee on the Plans for the Formulation of the Principles of the Nuremberg Charter and Judgment, para. 2(a), quoted in UNSG Nuremberg Report, supra note 129, at 21.

171. UNSG Nuremberg Report, supra note 129, at 21.

172. Bin Cheng, supra note 156, at 141 (noting that the conditions for a law-making resolution "appear to have been satisfied, at least formally, in the case of General Assembly resolution 96 (I) of 11 December 1946. ..”).

173. GA Res. 96(I), The Crime of Genocide, I 5, UN Doc. A/64/Add.1 (Dec. 11, 1946).

174. Id., ๆ 6.

175. $I d .$, ๆ 7 . 


\section{c. Res. 2625 E Res. 3314}

The primary General Assembly resolutions concerning aggression are Res. 2625, the Friendly Relations Declaration, ${ }^{176}$ and Res. 3314, the Definition of Aggression. ${ }^{177}$ Neither resolution, however, affirms that acts of aggression are directly criminalized by international law. In fact, neither resolution even provides much support for the criminality of aggression. The Friendly Relations Declaration deems only a war of aggression a "crime against peace for which there is responsibility under international law," 178 thereby implicitly contrasting wars of aggression (which are international crimes) with other kinds of unfriendly acts (which are not). The Definition of Aggression, in turn, makes that distinction explicit, affirming that "a war of aggression is a crime against international peace," while "[a]ggression gives rise to international responsibility." 179 The British insisted on the differentiation, because they wanted to ensure that any aggressive act other than a fullblown war of aggression-following the IMT, an invasion that results in actual hostilities between two states ${ }^{180}$ —would give rise only to state responsibility. ${ }^{181}$

\section{ILC Statements}

A fourth potential source of evidence for the DCT would be the ILC's codification of the Nuremberg Principles and the two Draft Codes of Offences Against the Peace and Security of Mankind. As noted earlier, all three specifically affirm that certain acts-international crimes-are directly criminalized by international law, irrespective of domestic criminalization.

The three ILC statements, however, actually provide no support for the DCT. To begin with, like the CPD, the ILC's commissioners were divided over whether the Nuremberg Principles reflected general international law. ${ }^{182}$ They were not even certain that the CPD wanted them to formulate universal principles. ${ }^{183}$ As a result, the ILC issued the Nuremberg Principles

176. G.A. Res. 2625 (XXV), annex, Declaration on Principles of International Law concerning Friendly Relations and Co-operation among States in accordance with the Charter of the United Nations (Oct. 24, 1970).

177. G.A. Res. 3314 (XXIX), annex, Definition of Aggression (Dec. 14, 1974).

178. Friendly Relations Declaration, supra note 176, art. 1.

179. Definition of Aggression, supra note 177, art. 5(2).

180. Kevin Jon Heller, The Nuremberg Military Tribunals and the Origins of International Criminal Law 180-81 (2011).

181. See Kirsten Sellars, 'Crimes against Peace' and International Law 280 (2013).

182. See, e.g., David S. Koller, The Nuremberg Legacy in the Historical Development of International Criminal Law, in I Historical Origins of International Criminal Law 572 (Morten Bergsmo et al. eds., 2014) ("Given the divergent views among its members, the ILC opted not to pass judgment on the consistency of the Nuremberg Principles with international law or on how such principles should be applied in the future.").

183. See Clive Parry, Some Considerations upon the Content of a Draft Code of Offences against the Peace and Security of Mankind, 3 INT'L L.Q. 208, 208-09 (1950) (quoting Report of International Law Commission covering its First Session, United Nations, General Assembly, Official Records, Fourth Session, Suplement No. 10, para. 26). 
in 1950 on the basis that they had been asked not "to express an appreciation of the principles applied in the Charter and the Judgment of the Tribunal at Nurnberg as principles of international law [but] . . merely to give formulation to those principles without any indication of their authority." 184 And even that caveat proved too much for states. The Sixth Committee was so hopelessly divided over the legal status of the Nuremberg Principles that the General Assembly "did not approve the principles but simply sent them to Member States for comment" 185 - thereby preventing them from having any significant law-making effect.

In contrast to the Nuremberg Principles, the ILC acknowledged from the beginning that the Draft Codes represented the progressive development of customary international law, not its codification. ${ }^{186}$ That does not mean, of course, that the Codes could not have contributed to the customary status of direct criminalization. But neither Code was ever approved by the General Assembly: the Assembly shelved the 1954 Draft Code "pending the work of a Special Committee set up to deal with the difficult issue of defining aggression," 187 and it simply took no action with regard the 1996 Draft Code. ${ }^{188}$ Whatever their "esteemed status," 189 therefore, the Draft Codes fail to qualify as either state practice or opinio juris in favor of direct criminalization.

\section{International Tribunals}

A final potential source of evidence for the DCT is the existence of international tribunals with jurisdiction over international crimes. Many scholars who endorse the idea of direct criminalization emphasize the connection between international crimes and international tribunals. Einarsen, for example, says that "[t]he difference between international crimes and transnational crimes ... lies in the fact that transnational crimes have not been included as distinct crimes in any international court statute." ${ }^{190}$ Cryer and his co-authors adopt the same distinction. ${ }^{191}$ And Wise says simply that, "[i]n its strictest possible sense, international criminal law would be the law applicable in an international criminal court having general jurisdic-

184. Id. at 208-09.

185. H-H. Jescheck, State Responsibility in International Criminal Law: A Study of the Nuremberg Trial, in Mettraux, supra note 127, at 412; see also Bing Bing Jia, The Relations Between Treaty and Custom, 9 Chinese J. InT'L L. 81, 103 (2010) (“. . . [T] The Sixth Committee of the UN General Assembly found such disagreement in the Commission's report that it was impossible to state the sense of the Committee after debate.").

186. See, e.g., Koller, supra note 182, at 574-75.

187. Id. at 577 .

188. Ciara DamgaArd, Individual Criminal Responsibility for Core International Crimes 48-49 (2008).

189. Id. at 49 .

190. EINARSEN, supra note 1 , at 160 .

191. Robert Cryer et al., An Introduction to International Criminal Law and ProceDure 4-5 (2nd ed. 2010); see also Patrick Robinson, The Missing Crimes, in I The Rome Statute of the International Criminal Court: A Commentary 508-09 (Antonio Cassese et al. eds., 2000). 
tion to try those who commit acts which international law proscribes and which it provides should be punished." 192

These scholars do not explicitly argue that the existence of international tribunals provides support for the DCT. Simma and Paulus likely speak for them, however, when they rely on international tribunals to explain how a positivist can believe that international law directly criminalizes violations of the laws of war-war crimes. They begin by noting that the Geneva Conventions do not help establish the "international character" of such violations, because they deem only grave breaches to be war crimes-and even then only impose an obligation on states to domestically criminalize them. ${ }^{193}$ They also acknowledge that "actual state practice is difficult to find here." ${ }^{194}$ But they still insist that war crimes should be considered international crimes, because states have created international tribunals with the jurisdiction to prosecute them:

Modern positivism . . . considers the acceptance of the practice of international bodies by states, e.g., in the cases of the Yugoslavia and Rwanda Tribunals and the Nuremberg and Tokyo Tribunals, as establishing the required opinio juris. By creating tribunals to punish offenders of humanitarian law, states have demonstrated that they regard violations of humanitarian law as punishable at the international level, and thus have added practice to thescant-existing record. ${ }^{195}$

This argument has the virtue of clarity. How do we know that certain acts are directly criminalized by international law? Because states have created international tribunals that have jurisdiction to prosecute them, making domestic criminalization unnecessary.

The first thing to note is that this defense of the DCT is significantly overbroad. The argument cannot be that any crime prosecuted by an international tribunal is directly criminalized by international law, because states can create international tribunals to prosecute anything they want - even crimes that have no claim to being international. ${ }^{196}$ The Special Court for Sierra Leone, for example, had jurisdiction over crimes set out in its Preven-

192. Edward M. Wise, Codification: Perspectives and Approaches, in 1 International Criminal LaW (M. Cherif Bassiouni ed., Transnational Publishers, Inc. 2d ed. 1999).

193. Simma \& Paulus, supra note 10, at 310-11.

194. Id. at 311.

195. Id.; cf. Dinstein, supra note 10, at 228-29 ("But perhaps it is characteristic that the true nature of war crimes as international offences was elucidated beyond doubt only as an outcome of the Nuremberg Trial, in other words, as a result of the fact that an international penal tribunal (albeit ad hoc) had been established.").

196. See, e.g., O’KeEfe, supra note 2, at 60 ("An international criminal tribunal enjoys whatever subject-matter jurisdiction is vested in it by its constituent instrument . . . and there is nothing to prevent the states or international organization which establishes the tribunal from conferring on it jurisdiction ratione materiae over specified municipal crimes. . .”). 
tion of Cruelty to Children Act 1926 and Malicious Damage Act 1861.197 And the Special Tribunal for Lebanon has jurisdiction only over domestic Lebanese crimes. ${ }^{198}$

How, then, might we distinguish between internationally-prosecuted crimes that are directly criminalized by international law and internationally-prosecuted crimes that are not? The most plausible answer is supplied by the universality criterion: an international crime is an act that an international tribunal can prosecute no matter where in the world it is committed-even in a state that considers the act legal—while an "ordinary" crime is an act that an international tribunal can prosecute only when committed on the territory of a state or by the nationals of a state that considers the act criminal.

Assume, for example, the United States, Canada, and Mexico conclude a treaty that deems killing an endangered brown bear an international crime and then establish a tribunal that, like the ICC, has territorial and activenationality jurisdiction over brown-bear killing. That tribunal would be international (because it was created by more than one state) and killing a brown bear would be criminal under international law (because it has been deemed a crime by an international convention). But killing a brown bear would still not qualify as a "true" international crime under the DCT. The DCT defines an international crime as an act that is universally criminal because it is directly criminalized by international law, regardless of domestic criminalization. The killing of a brown bear would not satisfy that definition: although it would be illegal for a Russian to kill a brown bear on American, Canadian, or Mexican territory, a Russian would be free to kill a brown bear on Russian territory - a purely non-international bear killingas long as Russia had not criminalized killing brown bears. The international illegality of killing a brown bear could thus be limited by domestic law-which is precisely what the DCT rules out.

The situation would be very different, of course, if the tribunal had universal jurisdiction over killing a brown bear. In that case, the tribunal would indeed be able to prosecute anyone who kills a brown bear anywhere in the world - even the Russian who kills a brown bear on Russian territory. Now brown-bear killing would qualify as an international crime under the DCT, because the international criminality of killing a brown bear would not (and more importantly could not) be limited by domestic criminalization. Brownbear killing would indeed be universally criminal under international law.

This analysis raises an obvious question: why couldn't the tribunal exercise universal jurisdiction over killing brown bears? The answer is that states

197. Statute of the Special Court for Sierra Leone, Sierra Leone-U.N., art. 5, Jan. 16, 2002, 2178 U.N.T.S. 137 (Jan. 16, 2002).

198. S.C. Res. 1757, attachment, art. 2(a), (May 30, 2007). 
create international tribunals by pooling their domestic jurisdiction, ${ }^{199}$ so they cannot create an international tribunal that has greater jurisdiction than they themselves possess. International law permits states to exercise territorial and active-nationality jurisdiction over any act they deem criminal, ${ }^{200}$ so the US, Canada, and Mexico are free to create an international tribunal that prosecutes brown-bear killing on their territory and by their nationals. But international law does not currently permit states to exercise universal jurisdiction over killing brown bears, so the United States, Canada, and Mexico could not create an international tribunal that exercises universal jurisdiction over brown-bear killing.

Only one kind of international tribunal, therefore, even potentially provides support for the DCT: namely, a tribunal formed by states to prosecute acts over which they are individually entitled to exercise universal jurisdiction. If universal jurisdiction exists over a particular act, states could delegate their universal jurisdiction to an international tribunal. That international tribunal would then itself have universal jurisdiction and would be able to prosecute the act no matter where it was committed-even in a state that refused to domestically criminalize it.

Notice, though, that this analysis suggests the internationality of a tribunal is much less important than the type of crime the tribunal prosecutes. An international tribunal created by 190 of 196 states would provide no support for the DCT if none of the acts it prosecuted permitted universal jurisdiction: although the pooled jurisdiction of those states would permit the tribunal to prosecute those acts almost everywhere in the world, there would still be states in which those acts could be committed without fear of prosecution. The international criminalization of the acts would thus still be limited by domestic law-which is exactly what the DCT prohibits.

Conversely, an international tribunal created by only two states would support the DCT as long as there was universal jurisdiction over the acts it prosecuted. Practical problems aside-evidence collection, extradition, and so on-the pooled jurisdiction of the two states would enable the tribunal to prosecute those acts no matter where they were committed. Those acts could thus be legitimately considered universally criminal under international law, because they would be punishable by an international tribunal even when committed in a state that refused to criminalize them.

There is, of course, a possible objection to this analysis: namely, that it confuses jurisdiction with criminality. Although no court can prosecute an

199. See e.g., Quincy Wright, The Law of Nuremberg, 41 AM. J. INT'L L. 38, 49 (1947) ("If each party to the Charter could exercise such jurisdiction individually, they can agree to set up an international tribunal to exercise the jurisdiction jointly."); Kaul \& Kress, supra note 142, at 145 (defending "the very simple idea that states must be entitled to do collectively what they have the power to do individually"); Alejandro Chehtman, The Philosophical Foundations of Extraterritorial Punishment 132 (2010) ("This delegation framework would successfully explain most aspects of the jurisdictional scope the ICC has as a matter of law.”).

200. See, e.g., CRYER ET al., supra note 191, at 46-47. 
act that is not criminal, an act can be criminal even if no court exists to prosecute it. ${ }^{201}$ At least in theory, therefore, an act could be directly criminalized by international law even if no international tribunal currently exists that has global jurisdiction over it.

If states could create an international tribunal with global reach but simply have not, this objection would have force. But it seems metaphysicalthe ICL version of a tree falling in the forest-to consider an act directly criminalized by international law even if states are not capable of creating an international tribunal that could prosecute that act no matter where it was committed. On the contrary, the impossibility of a genuinely universal international tribunal would serve as powerful evidence against the idea of direct criminalization, because it would foreground the dependence of international criminalization on domestic criminalization.

As we have seen, the pooling of domestic universal jurisdiction provides one mechanism for creating an international tribunal that could prosecute certain acts no matter where they are committed. Are there others? The most promising alternative would be the Security Council acting pursuant to Article 41 of the UN Charter, which authorizes the Council to "decide what measures not involving the use of armed force are to be employed to give effect to its decisions." ${ }^{202}$ If the Security Council could create the ICTY and ICTR over Serbia's and Rwanda's objections, could it not create-political obstacles aside-an international tribunal that had the authority to prosecute international crimes committed anywhere in the world, even in states that considered those acts legal?

Actually, no. The Security Council was able to create the ICTY and ICTR over Serbia and Rwanda's objections because Yugoslavia ${ }^{203}$ and Rwanda had ratified the UN Charter, thereby consenting to the Security Council's ability to take whatever measures it deemed necessary to restore international peace and security. ${ }^{204}$ The Security Council has no Chapter VII authority over states that are not members of the UN; with regard to them, it is only able to issue "non-binding recommendations and proposals." 205 So although the Security Council could create an international tribunal with nearly universal jurisdiction, it could not create one with jurisdiction over international

201. Meron, supra note 52, at 561.

202. U.N. Charter art. 41, 1 U.N.T.S. 16 (Oct. 24, 1945).

203. Serbia did not become a member of the UN until 2002. Although Yugoslavia might not have existed at the time of the ICTY's creation, its previous membership in the UN meant that it had consented to the Security Council exercising its authority on Yugoslav territory.

204. U.N. Charter, supra note 202, art. 4(1).

205. Bardo Fassbender, UN Security Council Reform and the Right of Veto: A Constitutional Perspective 90 (1998); see also Charter of the United Nations: A Commentary 1268 (Bruno Simma et al. eds., 2012) ("Particular problems arise with respect to enforcement measures against non-member States. Vis-a-vis these third States, the justification of measures can hardly be based on the Charter itself."). As De Wet notes, the Federal Republic of Germany and Switzerland both consistently took this position prior to becoming UN members. ErIKa DE WET, The Chapter VII Powers of ThE United Nations Security Council 98 (2004). 
crimes committed on the territory of states that are not members of the UN-the Vatican, Palestine, Kosovo, and perhaps Taiwan ${ }^{206}$ - or on the territory of any state that chose to leave the UN in the future. ${ }^{207}$ The universality of the international crimes prosecuted by such a tribunal would thus still be contingent upon the willingness of non-member states to consent to its jurisdiction, a limitation that is inconsistent with the idea of direct criminalization.

In short, an international tribunal must be based on universal jurisdiction for its practice to even potentially support the DCT. The actually-existing international tribunals thus contribute little to the customary status of direct criminalization. The Special Tribunal for Lebanon, the Special Court for Sierra Leone, and the ICTY are based solely on territorial jurisdiction, ${ }^{208}$ while the ICTR, ICC, and the Extraordinary Chambers in the Courts of Cambodia are based on territorial and active-nationality jurisdiction. ${ }^{209}$ In fact, only one international tribunal has ever exercised universal jurisdiction: the Special Panels for Serious Crimes (SPSC) in East Timor, which was created by the UN in $2000 .{ }^{210}$

It is important to note that these jurisdictional limits also doom any attempt to defend direct criminalization on the ground that few states have ever challenged the legitimacy of international tribunals prosecuting international crimes. ${ }^{211}$ There is no question that, in the right circumstances, inaction can count as state practice ${ }^{212}$ or opinio juris. ${ }^{213}$ With regard to direct criminalization, though, states' failure to protest the creation of the international tribunals does not qualify as either. Most importantly, as just noted, the SPSC - a toothless tribunal the UN promptly forgot ${ }^{214}$-is the only in-

206. See DE WET, supra note 205, at 97.

207. Such a tribunal could, of course, prosecute international crimes committed on the territory of a non-member state by a national of a member-state. We are dealing here with purely internal international crimes - the kind addressed by universal jurisdiction.

208. Statute of the Special Tribunal for Lebanon, Art. 1, S/RES/1757 (2007) (May 30, 2007); SCSL Statute, supra note 197, Art. 1(1); Statute of the International Criminal Tribunal for the Former Yugoslavia, Art. 1, SC Res. 827, UN Doc. S/RES/827 (May 25, 1993).

209. Law on the Establishment of the Extraordinary Chambers in the Courts of Cambodia for the Prosecution of Crimes Committed During the Period of Democratic Kampuchea, Art. 1, NS/RKM/ 1004/006 (Oct. 27, 2004); Statute of the International Criminal Tribunal for Rwanda, Art. 1, SC Res. 955, UN Doc. S/RES/955 (Nov. 8, 1994); Rome Statute, supra note 35, Art. 12(2).

210. Regulation on the Establishment of Panels with Exclusive Jurisdiction over Serious Criminal Offenses, § 2(1), UNTAET/REG/2000/15 (June 6, 2000).

211. Brazil and China both initially challenged the Security Council's authority to create the ICTY, but neither voted against Res. 827 and the Tribunal famously upheld its kompetenz-kompetenz in Tadić. See CRYER, supra note 54, at 53-54.

212. See ILA Custom Report, supra note 15, at 36; ILC Draft Conclusions, supra note 15, at 2.

213. See ILC Draft Conclusions, supra note 15, at 3 ("Failure to react over time to a practice may serve as evidence of acceptance as law (opinio juris), provided that States were in a position to react and the circumstances called for some reaction.").

214. See, e.g., David Cohen, Indifference and Accountability: The United Nations and the Politics of International Justice in East Timor, East-West Center Special Reports, No. 9 http:// www.eastwestcenter.org/publications/indifference-and-accountability-united-nations-and-politics-international-justice-east-. 
ternational tribunal whose jurisdiction even conceivably supports the idea of direct criminalization. States' acquiescence to the creation of tribunals with more limited forms of jurisdiction based on state consent cannot help establish direct criminalization.

Moreover, even if direct criminalization were the basis for the ICTY, ICTR, and SCSL being able to prosecute international crimes, their focus on specific conflicts involving a small number of states would make it difficult to view state silence as acquiescence. As Cryer has noted, states are willing to grant authority to "safe" international tribunals that they would never tolerate in "unsafe" international tribunals - tribunals whose rules might apply to them, as well. ${ }^{215}$ The creation of the ICTY, ICTR, and SCSL thus hardly "called for some reaction" on the part of unaffected states. ${ }^{216}$ Indeed, it is revealing that when states created the ICC, an "unsafe" tribunal, states pointedly refused to grant it universal jurisdiction.

\section{The Basis of Universal Jurisdiction}

But doesn't even the possibility of the international community creating a tribunal with universal jurisdiction over the core international crimes support the idea of direct criminalization? After all, it is widely assumed that customary international law permits states to exercise universal jurisdiction over war crimes, crimes against humanity, and genocide, ${ }^{217}$ and a number of scholars have pointed out that there was no legal reason why the ICC could not have been based on universal jurisdiction instead of on territorial and active-nationality jurisdiction. ${ }^{218}$

This argument, however, presumes that the existence of universal jurisdiction provides support for direct criminalization. In fact, that is not the case. Although universal jurisdiction clearly establishes that an act is universally criminal under international law, it does not necessarily establish that an act is directly criminalized by international law. The latter is true only if the availability of universal jurisdiction is a consequence of an act being directly criminalized by international law. If universal jurisdiction exists because all states are obligated to domestically criminalize an act, the existence of universal jurisdiction-and thus the possibility of its use by an international tribunal through delegation-supports the NCT, not the DCT.

215. CRYER, supra note 54, at 238.

216. ILC Draft Conclusions, supra note 15, at 3 (noting that silence in the face of a practice counts as acquiescence only if "the circumstances called for some reaction").

217. See, e.g., Colangelo, supra note 53, at 151.

218. See, e.g., Chentman, supra note 199, at 132 ("This delegation framework would successfully explain most aspects of the jurisdictional scope the ICC has as a matter of law. States would be able to delegate their territorial criminal jurisdiction to the ICC, and they would also be entitled to delegate their universal jurisdiction."); Bekou \& Cryer, supra note 142, at 50-51 ("States are entitled to assert universal jurisdiction over international crimes. The ICC operates on the basis of delegated jurisdiction from its State parties. They would, therefore, be entitled to have passed on universal jurisdiction to the ICC.”). 
A number of scholars who define an international crime as an act that is directly criminalized by international law also believe that one consequence of international criminalization is the availability of universal jurisdiction. ${ }^{219}$ Ambos, for example, claims that universal jurisdiction is the purest manifestation of direct criminalization: "universal prosecutability, in addition to individual criminal responsibility, results from the fact that only the former allows for prosecution irrespective of national laws (and traditional jurisdictional links), and that this is the only way in which states can express their serious interest in the recognition of a certain conduct as a crime under ICL stricto sensu." 220 In a similar vein, Kress argues that the "true test" for whether universal jurisdiction exists for a particular act "would seem to be whether states agree to the internationalization of the criminal law rule and create a crime under international law."221

This connection, however, raises an important question: what is the positivist basis for the idea that universal jurisdiction is a consequence of direct criminalization? We can imagine what such a basis would look like. A lawmaking treaty with universal or near-universal ratification, for example, could assert that a particular act is directly criminalized by international law and thus permits universal jurisdiction. But no such treaty exists. As we have seen, only one multilateral treaty actually affirms direct criminalization-the Statute of Limitations Convention—and that treaty says nothing about universal jurisdiction. Even more importantly, all of the treaties that do make use of universal jurisdiction - such as the Geneva Conventions and the Apartheid Convention-function as suppression conventions, requiring domestic criminalization.

Alternatively, a widely supported General Assembly resolution could affirm that universal jurisdiction is a consequence of direct criminalization.

219. See, e.g., Princeton Principles, supra note 17, at 28 ("Universal jurisdiction may be exercised by a competent and ordinary judicial body of any state in order to try a person duly accused of committing serious crimes under international law."); Kaul \& Kress, supra note 142, at 145 ("The universality approach starts from the assumption that, under current international law, all states may exercise universal jurisdiction over the above-listed core crimes of international law."); Robert Cryer, Royalism and the King: Article 21 of the Rome Statute and the Politics of Sources, 12 NEw CRIM. L. REv. 390, 394 (2009) (arguing that universal jurisdiction "only inheres over those crimes as defined in international law"); WERLE \& JESSBERGER, supra note 51, at 73 (noting that it follows from the universal nature of international crimes "that the international community is empowered to prosecute and punish these crimes, regardless of who committed them or against whom they were committed"); EINARSEN, supra note 1, at 139 (arguing that "the special character of the crimes themselves" is what justifies and implies "universal jurisdiction lex lata”).

220. Kai Ambos, II Treatise on International Criminal Law: The Crimes and Sentencing 227 (2014)

221. Claus Kress, Universal Jurisdiction over International Crimes and the Institut de Droit International, 4 J. Int'L CRim. Just. 561, 568 (2006). (emphasis in original); cf. Boister, supra note 10, at 963-64 (claiming that, because they are directly criminalized by international law, international crimes "are subject to a permissive 'pure' or 'absolute' universal jurisdiction established by general international law"); EINARSEN, supra note 1, at 139 (insisting on the international/transnational distinction, because if the distinction is blurred, "the procedural consequences of the crimes (universal jurisdiction) may be used to legally identify the 'international crimes' rather than the special character of the crimes themselves justifying and implying universal jurisdiction lex lata”). 
But no General Assembly resolution concerning the core international crimes even mentions universal jurisdiction.

Finally, and perhaps most promisingly, states could agree with Ambos and Kress and assert that their right to use universal jurisdiction flows from international law's direct criminalization of certain acts. Only South Africa, however, has explicitly taken that position ${ }^{222}$-and its own Constitutional Court disagrees. ${ }^{223}$ As discussed in more detail below, the overwhelming majority of states make use of universal jurisdiction in ways that are inconsistent with the idea of direct criminalization. Fifty-seven states incorporate universal jurisdiction only when a treaty requires them to do so. And 59 states view universal jurisdiction as a strictly subsidiary form of jurisdiction, available only when the territorial state is unwilling or unable to prosecute the act in question itself ${ }^{224}$ - a requirement that foregrounds the necessity of domestic criminalization.

From a positivist perspective, then, state practice and opinio juris provide negligible support for the idea that universal jurisdiction automatically flows from the direct criminalization of certain acts by international law. That connection seems to be little more than an article of faith-a naturalist idea that is not capable of being disconfirmed. If universal jurisdiction really is the only way "states can express their serious interest in the recognition of a certain conduct as a crime under ICL," it is reasonable to assume that states would have affirmed the connection themselves.

\section{Conclusion}

Almost without exception, ICL scholars have explained the universal criminality of the core international crimes-war crimes, crimes against humanity, genocide, and aggression-by claiming that they involve acts that are directly criminalized by international law, irrespective of domestic criminalization. This Part has demonstrated, however, that the positivist case for the DCT is extremely weak. The idea of direct criminalization emerges the most clearly in the IMT judgment and in the work of the ILC, but judgments and expert statements are merely subsidiary means for determining customary international law. Moreover, the most promising primary sources of custom-multilateral treaties, domestic criminalization and prosecutions, General Assembly resolutions, and the practice of international tribunals-not only provide little support for direct criminalization, they

222. Statement submitted by South Africa, reply to Sixty-Fifth U.N. G.A. on Universal Jurisdiction, supra note 19, at 2 (taking position that international crimes are "directly punishable under international law itself').

223. National Commissioner of the South African Police Service v. Southern African Human Rights Litigation Centre and Another, para. 61, 2015 (1) SA 315 (CC) (holding that "investigating international crimes committed abroad is permissible only if the country with jurisdiction is unwilling or unable to prosecute"). As explained in the next Part, subsidiarity is consistent with the NCT, not the DCT.

224. See Appendix. 
appear to support the very definition of an international crime as an act that international law obligates all states to domestically criminalize.

\section{THE NATIONAL CRIMINALIZATION THESIS}

\section{A. Definition}

Rejecting the direct-criminalization thesis on positivist grounds does not require abandoning the idea that international crimes are universally criminal. Nor does it mean rejecting the possibility of a positivist definition of an international crime. It simply means that we must consider a very different definition: namely, that an international crime is an act that international law obligates every state in the world to criminalize.

Thus defined, there are two basic aspects to the national-criminalization thesis. First, international law must obligate, not simply permit, states to criminalize a particular act. Authorization to criminalize an act is clearly not sufficient, because it leaves open the possibility that states will refuse to criminalize that act, which is inconsistent with the universality criterion for an international crime. Second, and relatedly, international law must obligate all states, not simply some states, to criminalize a particular act. If even one state is free to permit the commission of a particular act on its territory, that act cannot be considered universally criminal.

\section{B. Pedigree}

This definition of an international crime is clearly well outside of the ICL mainstream. But it is far from unprecedented. For example, there are naturalist intimations of the NCT in Grotius, who argued that international law prohibited states from giving refuge to an individual who had committed an "offence against human society" abroad. Faced with such a situation, Grotius insisted, "that State where the convicted Offender lives or has taken Shelter, should, upon Application being made to it, either punish the demanded Person according to his Demerits, or else deliver him up to be treated at the Discretion of the injured Party"225 —an aut dedere aut judicare obligation that is predicated upon domestic criminalization.

To be sure, Grotius believed that states had the right, not the obligation, to criminalize offences against human society, ${ }^{226}$ which means that his theory cannot be considered a direct forerunner of the NCT. Georg Schwarzenberger, by contrast, adopted a limited form of the NCT in his groundbreaking 1950 article "The Problem of an International Criminal

225. Hugo Grotius, II De Jure Belli ac Pacis, ch. XXI, 1062 (Richard Tuck ed., 2005).

226. Id. at 1061 (arguing, with regard to offences against human society, that "[s]ince the Establishment of States and Communities, it is judged reasonable to transfer this Right [of punishment] to the respective States or their Sovereigns, according to whose Discretion all Faults, as do properly concern them, are to be punished or remitted."). 
Law." Schwarzenberger specifically rejected the idea that international law directly criminalized acts such as war crimes and genocide. ${ }^{227}$ Instead, he believed that international law either permits or requires all states to criminalize certain acts - the latter being the defining characteristic of the NCT. War crimes fall into the first category, because international law simply permits states "to assume an extraordinary criminal jurisdiction under their own municipal law" for violations of the law of war. ${ }^{228}$ Piracy within territorial seas, however, falls into the second category: because "[e]very State is under an international obligation to suppress piracy" on its territory, "[t]o the extent to which, for the purpose of countering piracy, a State requires of necessity the assistance of its municipal criminal law, such law may be considered to be internationally prescribed." 229

Finally, until recently, ${ }^{230}$ Bassiouni-one of the primary architects of modern ICL-took the position that ICL was essentially conterminous with the NCT. When Bassiouni presented his draft international criminal code in 1980 , he made almost no mention of the possibility of international law directly criminalizing certain acts. Instead, he emphasized that ICL had originally developed through domestic criminalization obligations and would almost certainly continue to develop that way in the future:

The approach will remain the same; international criminal law will rely on the municipal legal system to enforce its criminal sanctions and on the international legal system to provide means by which a given municipal system will be required to carry out that task (e.g., by allowing universal jurisdiction, requiring prosecution or imposing a duty of extradition and developing new rules on extradition and cooperation in penal matters). Since all sources and aspects of international criminal law ultimately lead to the right or duty of a municipal system to prosecute (for internationally defined crimes relying upon the theory of universality) or in the alternative, the duty to extradite to another municipal system for such prosecution, it appears, therefore, that the only civitas maxima of international criminal law which now exists is the one proposed by Hugo Grotius in 1624: aut dedere aut punier with perhaps one modification that it should be aut dedere aut judicare. ${ }^{231}$

227. Schwarzenberger, ICL, supra note 76, at 295 ("II]n the present state of world society, international criminal law in any true sense does not exist.").

228. Id. at 270 .

229. Id. at 269.

230. Bassiouni now endorses the DCT. See M. Cherif Bassiouni, Crimes Against Humanity 475 (2011).

231. M. Cherif Bassiouni, International Criminal Law: A Draft International Criminal Code 24 (1980). 
The NCT is also not inconsistent with the IMT's insistence that international obligations transcend domestic ones. Recall the judgment's most famous paragraph, quoted above ${ }^{232}$ :

Crimes against international law are committed by men, not by abstract entities, and only by punishing individuals who commit such crimes can the provisions of international law be enforced ... individuals have international duties which transcend the national obligations of obedience imposed by the individual state.

Given the subsequent work of the ILC, the IMT judges almost certainly intended this paragraph to affirm the idea of direct criminalization. But it does not have to be read that way. The first sentence says only that individuals who violate international law have to be punished; it neither insists that punishment be imposed by an international tribunal directly applying international law nor rules out the possibility of states indirectly enforcing international law's prohibitions. Similarly, the second sentence says only that states cannot permit individuals to act in ways that international law forbids - a formulation that is in no way inconsistent with the idea that international law forbids an act by requiring all states to domestically criminalize it.

Like the NCT itself, this reading of the IMT judgment is not without precedent. In 1947, for example, Schwarzenberger denied that the judgment had created ICL in any "material sense"-namely as involving direct criminalization. On the contrary, he insisted, "[w]ithin the framework of the Charter, the Nuremberg Tribunal has extended the normal range of municipal jurisdiction in the field of criminal justice and, in this respect, assimilated jurisdiction in crimes under the Charter to jurisdiction in war crimes under customary international law." 233 Ten years later, Jescheck insisted that "one of the most important and most beneficial effects of the Nuremberg judgment" is "the recognition of criminal liability for serious offences against the international law of warfare and the obligation on states to prosecute them." ${ }^{334}$ And more recently, O'Keefe has acknowledged that ambiguities in the IMT judgment mean that "individual responsibility for a "crime against international law' or a 'crime under international law' could be characterized as a function of state responsibility and, additionally, as ultimately arising not under international law itself but under national law." 235

\section{Legal Foundation}

The NCT obviously presupposes that international law is capable of obligating all states to criminalize the commission of certain acts. There are two

232. See supra note 57.

233. Schwarzenberger, Judgment, supra note 133, at 188.

234. Jescheck, supra note 185 , at 417.

235. O'KeEFe, supra note 2 , at 75. 
possible sources for such an obligation. The first is straightforward: a universally-ratified treaty that requires domestic criminalization. Anything less than universal ratification does not suffice, because it leaves open the possibility that the act in question will remain legal in states that choose not to ratify the treaty.

The other possible source of a universal obligation to criminalize is customary international law. That source is more promising, because customary rules generally apply to all states equally. Once again, though, we are faced with the problem of persistent objection: if a state objects to the formation of a criminalization obligation, it will not be obligated to criminalize the act in question. The universality criterion thus likely limits international crimes to acts that states have a jus cogens obligation to criminalize, making persistent objection impossible.

This jus cogens requirement, however, raises a disquieting possibility: namely, that it may be difficult to defend the international criminality of at least some of the international crimes without resorting to a problematic naturalism. The secondary rules governing the creation of jus cogens norms are famously vague; indeed, the ILC itself acknowledged in its report on the Vienna Convention on the Law of Treaties (VCLT) - the treaty that first introduced the idea of $j u$ s cogens into positive law ${ }^{236}$ — that " $[\mathrm{t}]$ he formulation of the rule, however, is not free from difficulty, since there is not as yet a generally accepted criterion by which to identify a general rule of international law as having the character of jus cogens." 237 There is no question, though, that the evidentiary requirements for a jus cogens norm are exceptionally high — the logical consequence of the fact that such norms, unlike "ordinary" rules of custom, are specifically non-consensual, binding even states that persistently object to them. ${ }^{238}$ According to the VCLT, "a peremptory norm of general international law is a norm accepted and recognized by the international community of States as a whole."239 Universal agreement is not required; as Nieto-Navia notes, the VCLT drafting committee added the "as a whole" language to Art. 53 "to avoid a situation whereby one State could effectively veto a decision to designate a norm as peremptory." 240 But it is unclear how many states must accept and recog-

236. Vienna Convention on the Law of Treaties art. 53, May 23, 1969, 8 ILM 679, 1155 U.N.T.S. 331 [hereinafter VCLT].

237. Quoted in Eric Suy, Article 53, in The Vienna Convention on the Law of Treaties: A Commentary 1224, 1227 (Olivier Corten \& Pierre Klein eds., 2011).

238. See, e.g., Jure Vidmar, Norm Conflicts and Hierarchy in International Law: Towards a Vertical International Legal System?, in Hierarchy in International Law: The Place of Human Rights 13, 27 (Erika de Wet \& Jure Vidmar eds., 2012) (noting that "where peremptory norms are concerned, norms can be binding on a state not only without its consent but also despite the state's explicit opposition"); A. J. J. de Hoogh, The Relationship Between Jus Cogens, Obligations Erga Omnes and International Crimes: Peremptory Norms in Perspective, 42 Austrian J. Pub. InT'L L. 183, 186 (1991) ("To state that a norm is peremptory means that it is binding on all States alike, whether they are opposed to it or not.").

239. VCLT, supra note 236, art. 53.

240. Rafael Nieto-Navia, International Peremptory Norms (Jus Cogens) and International Humanitarian Law 10 (Mar. 2001) (unpublished article), http://www.iccnow.org/documents/WritingColombiaEng.pdf. 
nize a particular norm for it to represent the will of the "international community of States as a whole." According to the chairman of the drafting committee, "it would be enough if a very large majority did so" - a threshold designed to prevent "a very small number of States" from blocking the emergence of a jus cogens norm. ${ }^{241}$ What constitutes a "very large majority" or a "small number of States," the chairman regrettably failed to specify.

This uncertainty notwithstanding, state practice and opinio juris provide far greater support for the existence of universal, non-derogable obligations to criminalize than for the idea of direct criminalization. In particular, the NCT can rely on three material sources of international law that the DCT cannot:

1. A multilateral treaty that contains an obligation to domestically criminalize a particular act. By definition, such a treaty-a suppression conventiondoes not help establish direct criminalization. A suppression convention that is intended to have law-making effect and is very widely ratified, however, provides powerful evidence in favor of a universal obligation to criminalize. According to the ILC, conventions that deal with "serious crimes of international concern" are particularly likely to fall into the law-making category. ${ }^{242}$

2. National legislation incorporating international crimes into a state's penal code. As discussed earlier, such incorporation does not help establish direct criminalization, because there is almost no evidence that states incorporate international crimes because they believe the acts in question are directly criminalized by international law. By contrast, incorporation can help establish a universal obligation to criminalize-particularly when the incorporating state is not under a conventional obligation to do so. ${ }^{243}$

3. UNGA resolutions that affirm the obligation of states to domestically criminalize a particular act. Resolutions in this category provide significant evidence of a universal obligation to criminalize, particularly when adopted by a large majority of states and when states adopt a series of resolutions affirming the same rules. Such resolutions include those that affirm an aut dedere aut judicare obligation: because "the judicare part of the obligation to extradite or prosecute can only mean ... to submit the case to the competent authorities for the purpose of prosecution," ${ }^{244}$ the obligation necessarily requires (prior) domestic criminalization.

Given these material sources, can we say that states have a jus cogens obligation to criminalize acts traditionally viewed as international crimes?

241. Quoted in Suy, supra note 237, at 1228.

242. See ILC Extradite or Prosecute Paper, supra note 91, at 69.

243. See, e.g., ILA Custom Report, supra note 15, at 46 (noting that state practice counts toward the creation of a customary rule when "non-parties in relation to parties or between themselves adopt a practice in line with that prescribed (or authorized) by the treaty").

244. Van Steenberghe, supra note 149, at 1108. 


\section{War Crimes}

The strongest case for such an obligation concerns the grave breaches of the Geneva Conventions. ${ }^{245}$ The Geneva Conventions specifically require states parties "to enact any legislation necessary to provide effective penal sanctions for persons committing, or ordering to be committed, any of the grave breaches of the present Convention." ${ }^{246}$ The Conventions are quintessential examples of a "law-making treaty" in which "states elaborate their perception of international law upon any given topic or establish new rules which are to guide them for the future in their international conduct." 247 Their universal ratification thus strongly suggests that the obligation to criminalize grave breaches-like all of the Conventions' substantive obligations-would apply to any new state that might emerge, regardless of its willingness to be bound. ${ }^{248}$

Grave breaches of the First Additional Protocol are more complicated. AP I is intended to make general international law, but it is less widely ratified than the Geneva Conventions-174 states parties as of this writing, 89\% of the world's 196 states. ${ }^{249}$ That is still, however, a "very large majority of states." Moreover, a number of states not party to AP I or not party at the time of incorporation nevertheless criminalize one or more of the Protocolspecific grave breaches, including Azerbaijan, ${ }^{250}$ Bangladesh, ${ }^{251}$ Indonesia, ${ }^{252}$ Israel, ${ }^{253}$ Italy, ${ }^{254}$ and the United States. ${ }^{255}$ Such non-treaty-based practice provides additional evidence that the obligation to criminalize AP I grave breaches is, in fact, jus cogens.

Criminalizing war crimes in international armed conflict (IAC) that do not qualify as grave breaches also likely qualifies as a jus cogens obligation. Although states are not under any conventional obligation to criminalize such acts, approximately 140 have nevertheless criminalized one or more of

245. See, e.g., GC IV, supra note 103, art. 147.

246. Id., art. 146 .

247. Shaw, supra note 98, at 95; see also Brownlie's Public International Law, supra note 81, at 31 ("Although treaties are as such binding only on the parties, the number of parties, the explicit acceptance of these rules by states generally and, in some cases, the declaratory character of the provisions combine to produce a powerful law-creating effect."); Michael Wood (Special Rapporteur), Second Rep. on Identification of Customary International Law, 58, U.N. Doc. A/CN.4/672, at 57 (2014) ("[W]hen States accept (within the treaty or in the negotiations leading up to it or upon or after its adoption) that the treaty or certain provisions in it are declaratory of existing customary international law, this may serve as clear evidence of 'acceptance as law'.").

248. Cf. Darryl Robinson, Serving the Interests of Justice: Amnesties, Truth Commissions and the International Criminal Court, 14 Eur. J. INT'L L. 481, 490 (2003).

249. ICRC, https://ihl-databases.icrc.org/ihl/INTRO/470.

250. 1 ICRC CUSTOM STUdy Vol. I, supra note 134, at 576 n. 42.

251. 2 Int'l Comm. of the Red Cross, Customary International Humanitarian law: PracTICE 3863-64 (Jean-Marie Henckaerts \& Louise Doswald-Beck eds., 2005).

252. 1 ICRC CUSTOM STUdy, supra note 134, at 576 n. 42.

253. 2 ICRC CuSTOM STUdy, supra note 251, at 301-02.

254. 1 ICRC CUSTOM STUdy, supra note 134, at 576 n. 42 .

255. 2 ICRC CUSTOM STUdy, supra note 251, at 304-5. 
them. ${ }^{256}$ Moreover, a series of General Assembly resolutions adopted during the Cold War reinforce that practice by specifically affirming the duty of states to criminalize all war crimes in international armed conflict: Res. 2583 (XXIV), ${ }^{257}$ adopted in 1969 with 74 states voting in favor, five opposed, and 32 abstaining; Res. 2840 (XXVI), ${ }^{258}$ adopted in 1971 with 71 states voting in favor, no states voting against, and 42 states abstaining; and Res. 3074 (XXVIII), ${ }^{259}$ adopted in 1973 with 94 states voting in favor, no states voting against, and 20 states abstaining. As van Steenberghe notes, the 1971 and 1973 resolutions carry particular weight, because "no state voted against [them] and the reasons for abstention were not concerned with the recognition of an obligation to extradite or prosecute." ${ }^{260}$ Moreover, the General Assembly adopted a resolution by consensus in 2005-Res. 60/147 - that specifically affirms that all states have an obligation to criminalize "serious violations of international humanitarian law constituting crimes under international law." 261

The most difficult question is whether states have a jus cogens obligation to criminalize war crimes in non-international armed conflict (NIAC). There is no conventional obligation to criminalize those acts, and fewer states criminalize war crimes in NIAC than criminalize non-grave-breaches in IAC. That said, a number of factors nevertheless support the existence of a criminalization obligation. First, nearly 100 states do, in fact, criminalize war crimes in NIAC, despite the absence of any conventional obligation to do so. ${ }^{262}$ Second, although war crimes in NIAC did not exist when the General Assembly adopted Resolutions 2583, 2840, and 3074, they were well established by 2005, when it adopted Res. 60/147. Third, and most importantly, the General Assembly unanimously adopted Res. 50/200 in 1996, which specifically recalled and reaffirmed, in the context of the Rwanda

256. See Amnesty InTERnAtional, supra note 16 , at 12 .

257. G.A. Res. 2583 (XXIV), Question of the Punishment of War Criminals and of Persons who have Committed Crimes against Humanity (Question of Punishment), U.N. Doc. A/RES/2583, I 1 (Dec. 15, 1969) (calling upon "all the States concerned to take the necessary measures for . . . the detection, arrest, extradition, and punishment of all war criminals and persons guilty of crimes against humanity").

258. G.A. Res. 2840 (XXVI), Question of the Punishment of War Criminals and of Persons Who Have Committed Crimes Against Humanity, U.N. Doc. A/RES/2840, ๆ 4 (Dec. 18, 1971) (affirming "that refusal by States to cooperate in the arrest, extradition, trial, and punishment of persons guilty of war crimes and crimes against humanity is contrary to . . generally recognized norms of international law").

259. G.A. Res. 3074 (XXVIII), Principles of International Co-operation in the Detection, Arrest, Extradition and Punishment of Persons Guilty of War Crimes and Crimes against Humanity, U.N. Doc. A/9030/Add.1, I 5 (Dec. 3, 1973) (declaring that "Lp]ersons against whom there is evidence that they have committed war crimes and crimes against humanity shall be subject to trial . . as a general rule in the countries in which they committed those crimes").

260. Van Steenberghe notes that none of the states that abstained did so because they took issue with the obligation to criminalize. Van Steenberghe, supra note 149, at 1100.

261. G.A. Res. 60/147, annex, Basic Principles and Guidelines on the Right to a Remedy and Reparation for Victims of Gross Violations of International Human Rights Law and Serious Violations of International Humanitarian Law, U.N. Doc. A/RES/60/147, I 4 (Dec. 16, 2005).

262. See, e.g., 1 ICRC Custom Study Vol. I, supra note 134, at 591-603 (collecting examples). 
genocide and its connected NIAC, "the obligations of all states to punish all persons who commit . . grave violations of international humanitarian law."263

These material sources clearly count toward a jus cogens obligation to criminalize war crimes in NIAC. It is also possible to argue that the 124 ratifications of the Rome Statute, which criminalizes a wide variety of acts in NIAC, provide additional support for that obligation. Although the Rome Statute's principle of complementarity does not require states to incorporate the crimes in Articles 6-8, ${ }^{264}$ the Preamble to the Rome Statute specifically recalls "that it is the duty of every State to exercise its criminal jurisdiction over those responsible for international crimes."265 The use of "recalling" is particularly important, because it indicates that the drafters of the Rome Statute believed the duty to prosecute international crimes existed under customary international law prior to the Statute's adoption. ${ }^{266}$ Indeed, both states and scholars have read the Preamble to support the idea that customary international law obligates states to incorporate international crimes into their domestic penal codes. ${ }^{267}$

\section{Genocide}

There is also a very strong case to be made that states have a jus cogens obligation to criminalize genocide. 147 states have ratified the Genocide Convention, which requires state parties "to enact, in accordance with their respective Constitutions, the necessary legislation to give effect to the provisions of the present Convention." ${ }^{268}$ Approximately 118 states have actually criminalized genocide domestically ${ }^{269}$ - including 16 states that have not or had not at the time of incorporation ratified the Genocide Convention. ${ }^{270}$ General Assembly Res. 96(I), which was adopted unanimously and which Bin Cheng cites as a classic example of a resolution capable of creating instant custom, ${ }^{271}$ invited all states to criminalize genocide, while Res. 50/200 goes even further, recalling and reaffirming the obligation of all states to

263. See G.A. Res. 50/200, Situation of Human Rights in Rwanda, U.N. Doc. A/RES/50/200, pmbl., para. 6 (Mar. 11, 1996). The U.N. Commission on Human Rights took a similar position in the context of the conflict in Sierra Leone. See Commission on Human Rights Res. 1999/1, Situation of Human Rights in Sierra Leone, U.N. Doc. E/CN.4/RES/1999/1, I 2 (Apr. 6, 1999).

264. Kevin Jon Heller, A Sentence-Based Theory of Complementarity, 53 HaRv. InT'L L.J. 86, 88 (2012).

265. Rome Statute, supra note 35, pmbl., para. 6.

266. See Triffterer, supra note 9 , at 11.

267. See, e.g., Statement of Kenya, Sixth Committee, Summary Record of the 12th Meeting 8 [hereinafter 12th Meeting 2014], U.N. Doc. A/C.6/69/SR.12 (Dec. 9, 2014); D. Robinson, supra note 248, at 493; Antonio Cassese et al., The Rome Statute: a Tentative Assessment, in CASsESE ET AL., supra note 191, at 1906 (same).

268. Genocide Convention, supra note 118, art. V.

269. Amnesty International, supra note 16, at 13.

270. Andorra, Cape Verde, Central African Republic, Congo, Dominica, Eritrea, Guinea-Bissau, Indonesia, Kenya, Malta, Mauritius, Niger, Samoa, Somalia, Tajikistan, Turkmenistan. Id. at 16-21.

271. BIn Cheng, supra note 156, at 141. 
prosecute genocide. ${ }^{272}$ And finally, the Human Rights Council has consistently emphasized "the responsibility of each individual State to protect its population from genocide, which entails the prevention of such a crime, including incitement to it, through appropriate and necessary means." 273 Resolutions of international organizations count as the practice of the individual states that vote in favor of the resolution. ${ }^{274}$

\section{Crimes Against Humanity}

The case for a jus cogens obligation to criminalize crimes against humanity is more complicated, because only the Apartheid Convention specifically requires their criminalization and far fewer states have criminalized crimes against humanity - approximately 90-than have criminalized war crimes or genocide. ${ }^{275}$ Finding a jus cogens obligation to criminalize thus likely requires giving great weight to the Preamble of the Rome Statute, with the Statute's 125 ratifications, and to General Assembly resolutions like Res. 2840 and Res. 3074, both of which affirm the obligation to criminalize crimes against humanity as well as war crimes. ${ }^{276}$ Those material sources, in turn, are supported by the resolutions of other international organizationsparticularly Res. 2005/81 of the UN Commission on Human Rights, adopted by consensus, which "[r]ecognizes that States must prosecute or extradite perpetrators, including accomplices, of international crimes such as. . crimes against humanity. . . in accordance with their international obligations"277; and Res. 2225 of the Organization of American States, adopted unanimously, which urges member states "to combat impunity and to prosecute or extradite, in accordance with their obligations under international law, those responsible for all violations of . . . crimes against humanity . . . in order to bring them to justice." ${ }^{278}$

\section{Aggression}

It is extremely unlikely that states have a jus cogens obligation to criminalize aggression-even wars of aggression. Prior to the Rome Statute, no treaty encouraged states to criminalize aggression, much less required them to do so. Nor is it possible to base an obligation to criminalize aggression on General Assembly resolutions, because neither the Friendly Relations Declaration nor the Definition of Aggression requires criminalization. Moreover,

272. See G.A. Res. 50/200, supra note 263, Preamble, para. 6.

273. See, e.g., Human Rights Council Res. 22/22, U.N. Doc. A/HRC/22/L.30, ๆ 2 (Mar. 18, 2013).

274. See ILA Custom Report, supra note 15, at 19; ILC Draft Conclusions, supra note 15, at 2.

275. See Amnesty International, supra note 16, at 12-13.

276. See G.A. Res. 2840, supra note 258, ๆ 4; G.A. Res. 3074, supra note 259, I 5.

277. Comm'n on Human Rights, Res. 2005/81, U.N. Doc. E/CN.4/RES/2005/81, ๆ 2 (Apr. 21, 2005).

278. Org. of Am. States, AG/RES. 2225 (XXXVI-O/06), Cooperation among the Member States of the Organization of American States to Ensure the Protection of Human Rights and Fight Impunity, \ 1 (June 6, 2006). 
very few states actually criminalize aggression-approximately 37.279 The only conceivable basis for a jus cogens obligation is thus the Rome Statute, with its recently-adopted definition of aggression. But that is a difficult argument to make, given that only 32 states have ratified the aggression amendments and seven of those states had already criminalized aggression. ${ }^{280}$

\section{Universal Jurisdiction}

As we have seen in previous parts, there is a necessary connection between universal jurisdiction and the idea of universal criminality. Universal jurisdiction is the primary international-law vehicle for affirming the idea that certain acts are universally criminal. And it is precisely the possibility of delegating universal jurisdiction to an international tribunal that makes it possible - in theory if not yet in practice-for states to create an international tribunal that could prosecute international crimes no matter where they are committed.

We have also seen, however, that there is no positivist basis for the ideacritical to the DCT - that universal jurisdiction exists because certain acts are directly criminalized by international law. No treaty affirms that relationship. No UN resolution does. Only one state has explicitly affirmed that relationship in connection with its use of universal jurisdiction-and that state's own highest court disagrees.

The NCT, by contrast, provides a much stronger positivist explanation of universal jurisdiction. Simply put, considerable state practice and opinio juris indicate that universal jurisdiction depends upon a universal obligation to criminalize a particular act, because it is precisely a state's failure to prosecute an international crime committed on its territory that justifies other states disregarding traditional limits on extraterritorial jurisdiction.

First, when states draft a treaty that requires universal jurisdiction over a particular act, they almost always ${ }^{281}$ require domestic criminalization of that act, as well. That is true, as noted earlier, for the two treaties that concern the core international crimes: the Geneva Conventions and the Apartheid Convention. And it is true for suppression conventions generally, ${ }^{282}$ from the

279. See Status of Ratification and Implementation, The Global Campaign for Ratification And Implementation of the Kampala Amendments on the Crime of Aggression, http:/crimeofaggression.info/the-role-of-states/status-of-ratification-and-implementation/ (last updated Sept. 23, 2016).

280. Id.

281. The only exception seems to be UNCLOS, which does not specifically impose an obligation to domestically criminalize piracy. According to Boister, that lacuna "rests on the assumption that piracy is a crime in customary international law and there is no need for an explicit treaty obligation to criminalize piracy in national law." Neil Boister, An Introduction to Transnational Criminal Law 32 (2012).

282. See Michael P. Scharf, Application of Treaty-Based Universal Jurisdiction to Nationals of Non-Party States, 35 NEw ENGL. L. ReV. 363, 363-65 (2001) (collecting cites). 
1970 Hijacking Convention ${ }^{283}$ to the 1997 Terrorist Bombings Convention. ${ }^{284}$ The regular presence of both obligations does not prove that states view universal jurisdiction as a consequence of an obligation to criminalize, but it at least indicates that states believe there is an elective affinity between the two.

Second, 57 states provide for universal jurisdiction over an international crime only when they are formally required to do so by treaty. The list includes both powerful states such as Russia and China; weak states like Bulgaria and Lesotho; and states in five of the six inhabited continents. ${ }^{285}$ Such practice is again not definitive of a relationship between universal jurisdiction and the obligation to criminalize, but it clearly undermines the idea, inherent to the DCT, that universal jurisdiction is a consequence of certain acts being directly criminalized by international law, making domestic criminalization irrelevant. If that idea were true, we would expect a significant number of states to adopt universal jurisdiction for core international crimes even in the absence of a conventional obligation to do so. Yet few do.

Third - and most importantly—59 states explicitly condition the use of universal jurisdiction on the territorial state being either unwilling or unable to prosecute an international crime. ${ }^{286}$ A minority of those states, 28, require the international crime to actually be criminal in the territorial state-a double criminality requirement much like the one commonly found in extradition treaties. Serbia's universal jurisdiction provision is an example:

Criminal legislation of Serbia shall also apply to a foreigner who commits a criminal offence abroad against a foreign state or foreign citizen, when such offence is punishable by five years' imprisonment or a heavier penalty, pursuant to laws of the country of commission, if such person is found on the territory of Serbia and is not extradited to the foreign state. 287

The other 31 states are also willing to exercise universal jurisdiction when the territorial state is unable to prosecute an act because it has failed to incorporate the relevant international crime into its penal code. ${ }^{288}$ El Salvador is typical:

283. Convention for the Suppression of Unlawful Acts Against the Safety of Civil Aviation, arts. 2-3, 4(b), concluded Sept. 23, 1971, 24 U.S.T. 564, 974 U.N.T.S. 177.

284. International Convention for the Suppression of Terrorist Bombings, Arts. 4(a), 6, adopted Jan. 12, 1998, 2149 U.N.T.S. 256.

285. All except Australia. Seven states also provide for universal jurisdiction over an international crime when they believe a treaty permits it: Argentina, Belarus, Bulgaria, Ghana, Samoa, Trinidad and Tobago, Uganda. See Appendix.

286. See id.

287. Criminal Code of the Republic of Serbia, Art. 9, Feb. 2006, http://www.osce.org/serbia/ 18244 ? download $=$ true.

288. See Appendix. 
$[I] t$ is incumbent on each State to prohibit particularly grave offences within its domestic legal system, as well as on the consequent obligation of the State to exercise its jurisdiction when such offences are committed on its territory. Furthermore, the recognition of the principle of universal jurisdiction has established the possibility that one State may exercise its jurisdiction in the face of the inaction or ineffectuality of another. ${ }^{289}$

The practice of the states in both of these categories explicitly supports the NCT. All 59 states view universal jurisdiction as a subsidiary form of jurisdiction, one that can be used only when a state violates an international obligation to effectively prosecute an international crime committed on its territory. ${ }^{290}$ All 59 thus view universal jurisdiction as dependent upon a preexisting obligation to criminalize, because a state cannot have an international obligation to effectively prosecute an international crime committed on its territory if it is not obligated to domestically criminalize that international crime in the first place. ${ }^{291}$ In other words, as El Salvador's statement explicitly affirms, an obligation to criminalize is inherent in the obligation to prosecute.

Like the NCT itself, the idea that universal jurisdiction is a subsidiary form of jurisdiction, available only when the territorial state has failed to criminalize or prosecute an international crime, has a long pedigree. The first serious international attempt to formulate the legal principles governing universal jurisdiction-the 1935 Draft Convention on Jurisdiction with Respect to Crime, prepared by the Harvard Research Project-adopted both double criminality and subsidiarity, permitting states to exercise universal jurisdiction only "if the act or omission which constitutes the crime is also an offence by the law of the place where it was committed, if surrender of the alien for prosecution has been offered to such other State or States and the offer remains unaccepted." 292 Similarly, two judgments routinely cited as the earliest examples of courts affirming universal jurisdiction-the NMT's judgments in the Hostage and Einsatzgruppen ${ }^{293}$ cases-each explicitly conditioned universal jurisdiction on the failure of the territorial state to adequately address the commission of an international crime. In the Hostage

289. Statement submitted by El Salvador, reply to Sixty-Fifth U.N. G.A. on Universal Jurisdiction, supra note 18 , at 5 .

290. See, e.g., id., Statement of Belgium I 5 ("Accordingly, the rationale for universal jurisdiction is to ensure that the perpetrators of the most serious crimes can be prosecuted when no other otherwise competent court is able or willing to initiate proceedings. Universal jurisdiction is in a sense subsidiary to the jurisdiction of the State in the territory of which a crime was committed.").

291. See, e.g., Questions Relating to the Obligation to Prosecute or Extradite (hereinafter "Belgium v. Senegal"), Judgment, 2012 I.C.J. Rep. 422, ๆ 74.

292. Harvard Research in International Law: Contemporary Analysis and Appraisal 489 (John P. Grant \& J. Craig Barker eds., 2007).

293. Einsatzgruppen: see, e.g., Stephen Macedo, Universal Jurisdiction: National Courts and the Prosecution of Serious Crimes Under International Law 231-32 (2004). Hostage: see Prosecutor v. Kallon E Kamara, Case No. SCSL-2004-15-AR72(E), Decision on Challenge to Jurisdiction, Ø 68 (Mar. 13, 2004). 
case, the tribunal emphasized that universal jurisdiction exists over "an act universally recognized as criminal" as long as "for some valid reason [it] cannot be left within the exclusive jurisdiction of the state that would have control over it under ordinary circumstances." 294 In Einsaztgruppen, the tribunal took a similar position with regard to universal jurisdiction over crimes against humanity:

Crimes against humanity are acts committed in the course of wholesale and systematic violation of life and liberty. It is to be observed that insofar as international jurisdiction is concerned, the concept of crimes against humanity does not apply to offenses for which the criminal code of any well-ordered state makes adequate provision. They can only come within the purview of this basic code of humanity because the state involved, owing to indifference, impotency or complicity, has been unable or has refused to halt the crimes and punish the criminals. ${ }^{295}$

Contemporary courts have also affirmed the subsidiary nature of universal jurisdiction. In the Zimbabwe Torture Docket case, for example, the Constitutional Court of South Africa held with regard to a universal-jurisdiction prosecution that "investigating international crimes committed abroad is permissible only if the country with jurisdiction is unwilling or unable to prosecute ... . Simply put, we may not investigate or prosecute international crimes in breach of considerations of complementarity and subsidiarity."296

Moreover, although not strictly relevant from a positivist perspective, it is worth noting that all of the leading philosophic defenses of universal jurisdiction-from Vattel ${ }^{297}$ onward-explain the permissibility of such jurisdiction by invoking the failure of the territorial state to address the commission of an international crime. ${ }^{298}$ Win-Chiat Lee's argument is typi-

294. Hostage, supra note 31, at 1241.

295. United States of America v. Otto Oblendorf et al. (hereinafter "Einsatzgruppen"), TWC IV, at 498 (1948)

296. National Commissioner of The South African Police Service, supra note 223, If 61.

297. See Vattel, quoted in Luc Reydams, Universal Jurisdiction: International and Municipal Legal Perspectives 36 (2003) (noting that although "pirates are sent to the gibbet by the first into whose hands they fall," if "the sovereign of the country where the crimes of that nature have been committed, reclaims the perpetrators of them in order to bring them to punishment, they ought to be surrendered to him, as being the person who is principally interested in punishing them in an exemplary manner").

298. See Noah Feldman, Cosmopolitan Law, 116 YALE L.J. 1022, 1065 (2007) (claiming that the argument for universal jurisdiction "rests not on the notion that some wrongs are so grave that they must be unlawful, but rather on the proposition that actually existing legal systems must address grave wrongs that come before them if they are to justify their existence"); Anthony Sammons, The Under-Theorization of Universal Jurisdiction: Implications for Legitimacy on Trials of War Criminals by National Courts, 21 BeRKELEY J. INT'L L. 111, 115 (2003) (“' $[T]$ he valid assertion of universal jurisdiction as the sole basis for the prosecution of international crimes requires a conclusion that the state of the perpetrator's nationality, or of the crime's commission, either has breached or failed to enforce its international obligations to such a degree that partial assumption of its domestic jurisdiction is permissible."); R. A. Duff, Criminal Respon- 
cal. After noting that states normally have exclusive legitimate authority to punish crimes committed on their territory, he argues that states lose that exclusivity when they fail to punish serious international crimes:

In the case of international crimes proper, however, that legitimate authority is compromised by the serious harm perpetrated against individuals under either state sponsorship or state acquiescence. Therefore, it can no longer act as the preemptory or overriding moral consideration that trumps others' rights and duties to bring about accountability for these crimes . . . . In this way, universal jurisdiction over international crimes proper is really nothing more than the corollary of the state's loss of legitimacy in monopolizing adjudication and punishment, in the form of exclusive jurisdictions, in relation to these crimes. ${ }^{299}$

Insisting on the subsidiary nature of universal jurisdiction, however, raises an important legal question: why should one state's failure to prosecute an international crime committed on its territory permit any other state to exercise jurisdiction over that crime? The only plausible answer is that states view failing to prosecute an international crime as a violation of an erga omnes obligation-an obligation owed to "the international community as a whole." 300 As Kadelbach explains, all states are entitled to respond to violations of erga omnes obligations, even those that are not directly harmed by them:

Being defined as obligations vis-à-vis the international community of States, they impose special duties on the offending State which may go beyond the bilateral reparation scheme which applies in reciprocal legal relationships. One of its elements is the right of States not directly affected by an internationally wrongful act to invoke the responsibility of the violator, be it on their own behalf, on behalf of subjects of international law who are not in a

sibility, Municipal and International 25 (unpublished manuscript), http://www.trinitinture.com/documents/duff.pdf ("[W]e see local or national jurisdiction as the default position (bearing in mind that we are focusing here only on crimes whose direct impact does not transcend national boundaries), and see an international court [or domestic court] with universal jurisdiction as a safeguard or fallback for cases with which, for whatever reason, the national courts cannot be expected to deal adequately."); Andrew Altman \& Christopher Heath Wellman, A Defence of International Criminal Law, 115 ETHICs 35, 46 (2004) (arguing, in the context of universal jurisdiction, that a state's right to "exclusive jurisdiction over matters that concern only those within its territorial borders ... rests on the state's satisfactory performance of the requisite political functions"); CHEHTMAN, supra note 199, at 101-02 ("Arguably, individuals in $\mathrm{S}$ have a fundamental interest in there being a criminal rule in force in $\mathrm{S}$ against acts of torture, murder, and the like perpetrated as part of a widespread or systematic attack. Moreover, this interest is not only incompatible with S holding an immunity against an extraterritorial authority punishing the perpetrators of these international crimes, but also overrides the interest that explains that immunity.").

299. Win-chiat Lee, supra note 74 , at 32 (footnote omitted).

300. Barcelona Traction, Light \& Power Co. (Belg. v. Spain), Judgment, 1970 I.C.J. Rep. 3, para. 33 (Feb. 5) [hereinafter Barcelona Traction]. 
position to bring a claim themselves, or simply as members of the international community of States. ${ }^{301}$

This explanation of universal jurisdiction, of course, raises a second important question: why do states have an erga omnes obligation to prosecute international crimes committed on their territory? The answer brings us back to the analysis presented above: because the defining characteristic of an international crime is that all states have a jus cogens obligation to domestically criminalize the act in question. It is generally accepted, following the ICJ's suggestion in Barcelona Traction ${ }^{302}$ and its more specific (and more recent) judgment in Belgium v. Senegal, ${ }^{303}$ that jus cogens norms give rise to correlative erga omnes obligations. ${ }^{304}$ A state's violation of a jus cogens obligation to criminalize an international crime committed on its territory thus violates an erga omnes obligation as well, thereby permitting all other states to exercise universal jurisdiction over that crime.

A few legal scholars have specifically made this argument, ${ }^{305}$ as has the UN Office of the High Commissioner for Human Rights. ${ }^{306}$ More importantly, in Jorgić v. Germany, the European Court of Human Rights, following Germany's Federal Constitutional Court, specifically relied on the relationship between jus cogens norms and erga omnes obligations to justify Germany's

301. Stefan Kadelbach, Jus Cogens, Obligations Erga Omnes and other Rules-The Identification of Fundamental Norms, in The Fundamental Rules of the International Legal Order: Jus Cogens Obligations and Erga Omnes 21, 26 (Christian Tomuschat \& Jean-Marc Thouvenin eds., 2006); see also Władysław Czapliński, Jus Cogens, Obligations Erga Omnes and International Criminal Responsibility, in THE Legal Regime of the International Criminal Court: Essays in Honour of Professor Igor Bilshchenko 403, 407 (Jose Doria et al. eds., 2009) (same).

302. See Barcelona Traction, supra note 300, at paras. 33-34 (explaining that "obligations of a State towards the international community as a whole" derive from prohibitions on acts such as aggression and genocide).

303. Belgium v. Senegal, supra note 291, at para. 68.

304. See, e.g., Rosanne Van Alebeek, The Pinochet Case: International Human Rights Law on Trial, 71 BRIT. Y.B. INT'L L. 29, 34 (2000) (“[JJus cogens norms and obligations erga omnes are two sides of the same coin.") (italicization omitted).

305. See, e.g., id. at 35 ("For present purposes it suffices to conclude that jus cogens norms necessarily apply erga omnes and that all States have a legal interest in their protection. The principle of universal jurisdiction can be said to follow from this legal interest in the protection of jus cogens norms.") (italicization omitted) (footnote omitted); Kenneth C. Randall, Universal Jurisdiction Under International Law, 66 Tex. L. Rev. 785, 831 (1988) (same); cf. Carlo Focarelli, International Law as Social Construct: The Struggle for Global Justice 475 (2012) ("There seems to be a necessary connection between universal jurisdiction and obligations erga omnes, assuming that a violation of international law towards all states gives all of them an exceptional title to exercise their criminal jurisdiction without any further jurisdictional link being necessary .....") (italicization omitted); Antonio Cassese, When May Senior State Officials Be Tried for International Crimes? Some Comments on the Congo v. Belgium Case, 13 Eur. J. INT'L L. 853, 859 (2002) (arguing that, with regard to the perpetrators of international crimes, "one is at a loss to understand why, if the national or territorial state fails to take proceedings, another state should not be entitled to prosecute and try them in the interest of the whole international community").

306. See U.N. Office of the High Comm'r for Human Rights, Nepal Conflict Report 67 (Oct. 2012), http://www.ohchr.org/Documents/Countries/NP/OHCHR_Nepal_Conflict_Report2012.pdf ("Universal jurisdiction exists on the premise that some international norms are erga omnes, meaning that the obligation is owed to the international community as a whole.") (italicization omitted) (footnote omitted). 
exercise of universal jurisdiction (on a subsidiary basis) over an act of genocide:

[T]he Contracting Parties to the Genocide Convention, despite proposals in earlier drafts to that effect, had not agreed to codify the principle of universal jurisdiction over genocide for the domestic courts of all Contracting States in that Article . . . However, pursuant to Article I of the Genocide Convention, the Contracting Parties were under an erga omnes obligation to prevent and punish genocide, the prohibition of which forms part of the jus cogens. In view of this, the national courts' reasoning that the purpose of the Genocide Convention, as expressed notably in that Article, did not exclude jurisdiction for the punishment of genocide by States whose laws establish extraterritoriality in this respect must be considered as reasonable (and indeed convincing). ${ }^{307}$

The ICTY took a similar position in Furundžija regarding universal jurisdiction over torture, defending the existence of such jurisdiction on the ground that Serbia's jus cogens obligation to criminalize torture implied an erga omnes obligation to prosecute acts of torture committed on its territory. ${ }^{308}$

In short, the most compelling positivist rationale for universal jurisdiction is that because all states are obligated to criminalize acts that qualify as international crimes, a state violates an obligation toward the international community as a whole when it allows an international crime to be committed on its territory-regardless of whether it considers the act in question to be legal or considers the act criminal but refuses to prosecute it. Either way, it is that state's violation of the erga omnes obligation that justifies the (adjudicative) intervention of another state that has no preexisting connection to the international crime.

\section{E. Conclusion}

Part III demonstrated that even the most generous understanding of positivism is incapable of justifying the idea that international crimes are directly criminalized by international law. This Part has demonstrated that the NCT thesis has a much stronger positivist foundation. Indeed, it seems clear that, at a minimum, international law imposes a jus cogens obligation on states to domestically criminalize war crimes and genocide, justifying their status as core international crimes.

The status of crimes against humanity under the NCT is less clear, but it is most likely possible to find a jus cogens obligation if we emphasize the lawmaking effect of the Preamble to the Rome Statute and resolutions of vari-

307. Jorgić v. Germany, 2007-III Eur. Ct. H.R. 263, 287 (italicization omitted).

308. See Furundžija, supra note 33, paras. 151-56. 
ous international organizations. We can also count the practice of the thirtythree states that make universal jurisdiction available for crimes against humanity but view universal jurisdiction as a subsidiary jurisdictional form. ${ }^{309}$ As we have seen, states in that category assume-either implicitly or explicitly-that all states have an obligation to criminalize crimes against humanity.

Aggression, however, is a different story. It is simply not possible to argue that international law obligates all states to criminalize aggression, which means that aggression is not universally criminal under international law and cannot be considered-at least from a positivist perspective-a true international crime. And that has two consequences. First, it means that states are not entitled to exercise universal jurisdiction over aggression, because it is widely accepted that the principle of non-intervention limits states to exercising universal jurisdiction over acts that genuinely qualify as international crimes. ${ }^{310}$ Second, it means that states could not create an international tribunal capable of prosecuting an act of aggression no matter where in the world it was committed. The jurisdiction of any such tribunal would be limited to the pooled territorial and active-nationality jurisdiction of the states that chose to join it - and would thus exclude acts of aggression committed both by and against states that were not members of the tribunal.

\section{THE INTERNATIONAL/TRANSNATIONAL DISTINCTION}

Rejecting the DCT in favor of the NCT does not require us to fundamentally rethink the status of the core international crimes. It does, however, undermine the traditional distinction between international and transnational crimes. The DCT establishes a categorical distinction between the two: international crimes are acts that are directly criminalized by international law; transnational crimes are acts that individual states criminalize domestically in response to obligations imposed by suppression conventions. Milanovićs formulation of the difference is typical:

309. Argentina, Australia, Azerbaijan, Belgium, Bosnia, Burundi, Cameroon, Canada, Chile, Comoros, Congo, Croatia, Cuba, Czech Republic, Denmark, El Salvador, Ethiopia, France, Germany, Hungary, Israel, Kenya, Macedonia, Montenegro, Netherlands, New Zealand, Norway, Panama, Slovakia, Slovenia, Somalia, Switzerland, Vietnam. This list is generated by cross-referencing the list of states that view universal jurisdiction as subsidiary, see Appendix, with Amnesty International's list of states that have universal jurisdiction over crimes against humanity, see AMNESTY INTERNATIONAL, supra note 16 , at $16-21$.

310. See, e.g., Kai Ambos, Treatise on International Criminal Law: Volume III: International Criminal Procedure 226-27 (2016); Florian Jessberger, Universal Jurisdiction, in Oxford Companion to International Criminal Justice 556 (Antonio Cassese et al. eds., 2009); Florian Jessberger, The Principle of Universal Jurisdiction in German Criminal Law 4 (unpublished manuscript), https://www.jura.uni-hamburg.de/ueber-die-fakultaet/professuren/professur-jessberger/forschung/

landesbericht-jessberger-2007.pdf. 
The so-called "suppression conventions," such as the UN Convention Against Torture, or the Convention for the Suppression of Terrorist Bombings . . . only create a state obligation to criminalize certain acts domestically, without binding individuals directly, and unlike genocide, without having parallel customary incriminations. These are not "true" or "core" international crimes, which create individual responsibility independently of domestic law, but merely "treaty" crimes, which cannot be punished in the absence of incrimination under domestic law. ${ }^{311}$

Now that we have rejected the DCT in favor of the NCT, we can see that the international/transnational distinction is untenable. Because an international crime is an act that all states have a jus cogens obligation to domestically criminalize, not an act that is directly criminalized by international law, a suppression convention is no less capable of creating an international crime than any other material source of custom. After all, as noted earlier, it is not only generally accepted that law-making treaties are capable of contributing to the formation of customary international law, the ICJ has even held (controversially) that "very widespread and representative participation in [a] convention might suffice of itself, provided it included that of States whose interests were specially affected." 312 There is thus no reason why an act deemed criminal by an exceptionally successful suppression convention should not be considered a true international crime-especially where the criminality of that act is buttressed by practice outside of the convention and by normative resolutions of various international organizations. ${ }^{313}$ As long as the obligation to criminalize the act in question is jus cogens, states would be entitled to exercise universal jurisdiction over the act and could delegate that jurisdiction to an international tribunal, enabling it to prosecute the act no matter where in the world it was committed. That act would thus satisfy the universality criterion that is the defining characteristic of an international crime.

In fact, two acts normally considered transnational crimes already have a very strong claim to international status under the NCT: torture and the financing of terrorism.

311. Marko Milanović, Is the Rome Statute Binding on Individuals? (And Why We Should Care), $9 \mathrm{~J}$. Int'L Crim. Just. 25, 28 (2011); see also Simma \& Paulus, supra note 10, at 308.

312. North Sea Continental Shelf, supra note 62, at 43.

313. Cf. P. Robinson, supra note 191, at 509-10 (noting, with regard to terrorism, that "the real distinction between core crimes and treaty crimes . . . and those established by treaties . . consists in the level and quality of support for them from the international community, that is, generality of practice as the quantitative index of customary law, and the sense of legal obligation (opinio juris) as the qualitative index of that law"). 


\section{A. Torture}

Although torture clearly qualifies as an international crime when it is committed in the context of an armed conflict (a war crime ${ }^{314}$ ) or as part of a widespread and systematic attack on a civilian population (a crime against humanity $\left.{ }^{315}\right)$, few scholars consider an individual act of torture during peacetime to be an international crime-even an act that satisfies the statecentered definition of torture in the Torture Convention. ${ }^{316}$ Ambos insists, for example, that "isolated incidents of torture do not amount to true international crimes," 317 because they do not entail "a serious violation of universal values and produce a collective concern among the international community." 318 Similarly, Boister says that torture does not "shock the conscience of international society sufficiently for it to take the step of classifying torture as an international crime stricto sensu." 319

A very strong case can be made, however, that international law imposes a jus cogens obligation on all states to criminalize acts of state-sponsored torture. The Torture Convention itself, which requires each state party to "ensure that all acts of torture are offences under its criminal law," 320 has been ratified by more than eighty percent of the world's states-159. ${ }^{321}$ The Convention clearly has "very widespread and representative participation," given that state parties come from every region in the world and include all of the world's major legal traditions, and it has even been ratified by "specially affected states" that are particularly notorious for state-sponsored torture, such as Jordan, Egypt, Syria, and the United States. ${ }^{322}$ Twenty-five states, including those with particularly ignoble histories of state-sponsored torture, have also ratified the American Convention on Human Rights, which categorically guarantees the right to be free from torture ${ }^{323}$ and requires each state party to "adopt, in accordance with their constitutional processes and the provisions of this Convention, such legislative or other measures as may be necessary to give effect to those rights or freedoms." 324

A significant number of states have acted on their treaty obligations. At least ninety have incorporated the Torture Convention's definition of torture

314. Rome Statute, supra note 35, art. 8(2)(a)(ii).

315. Id., art. 7(1)(f).

316. See Convention against Torture and Other Cruel, Inhuman or Degrading Treatment or Punishment, art. 1(1), Dec. 10, 1984, 1465 U.N.T.S. 24841 (requiring the severe pain or suffering be "inflicted by or at the instigation of or with the consent or acquiescence of a public official or other person acting in an official capacity") [hereinafter "Torture Convention"].

317. Амвоs, ICL Vol. II, supra note 220, at 245.

318. Id. at 227.

319. Boister, supra note 10, at 967.

320. Torture Convention, supra note 316, art. 4(1).

321. See U.N. Office of the High Comm'r for Human Rights, Status of Ratifications Interactive Dashboard, Convention Against Torture, http://indicators.ohchr.org/ (last updated Feb. 20, 2017) [hereinafter "Ratifications Interactive Dashboard, Convention Against Torture"].

322. Id.

323. American Convention on Human Rights, art. 5(2), Nov. 22, 1969, 1144 U.N.T.S. 123.

324. Id., art. 2. 
into their domestic law ${ }^{325}$ - more than have criminalized crimes against humanity. Moreover, four states that have not ratified the Torture Convention nevertheless criminalize torture: Bhutan, Comoros, Haiti, and Sudan. ${ }^{326}$ Practice of non-parties that is consistent with a treaty is widely considered to provide compelling evidence that treaty provisions have led to the creation of a parallel customary rule. ${ }^{327}$ Eighty-five states also permit their courts to exercise universal jurisdiction over torture ${ }^{328}$ — again more than for crimes against humanity - and thirty-six of those states view universal jurisdiction as subsidiary to territorial jurisdiction. ${ }^{329}$

The General Assembly has also consistently emphasized that states have an obligation to criminalize torture. In 1975, the General Assembly adopted without a vote the Declaration on the Protection of All Persons from Being Subjected to Torture, ${ }^{330}$ which provides that " $[\mathrm{e}] \mathrm{ach}$ State shall ensure that all acts of torture as defined in article 1 are offences under its criminal law." ${ }_{331}$ In 1977, the General Assembly adopted Resolution 32/64 without a vote, calling upon all Member States to unilaterally declare that they intended, inter alia, to "implement through legislation, and other effective measures, the provisions of said Declaration." ${ }^{332}$ And, of course, the General Assembly adopts a resolution every year without a vote that affirms the illegality of torture and "stresses that all acts of torture must be made offences under domestic criminal law punishable by appropriate penalties that take into account their grave nature." 333

Given this consistent state practice in favor of a universal obligation to criminalize state-sponsored torture, how can scholars plausibly maintain that isolated acts of torture are not international crimes because they fail to sufficiently "shock the conscience of international society" or do not involve "a serious violation of universal values"? That position is impossible to reconcile with the widespread ratification of the Torture Convention, the significant domestic criminalization of state-sponsored torture (including by non-party states), and the General Assembly's repeated condemnation of

325. See Amnesty International, supra note 16, at 13.

326. See Status of Ratifications Interactive Dashboard, Convention Against Torture, supra note 321.

327. See SHAw, supra note 98, at 96 ("[T]reaty provisions may lead to custom providing other states, parties and non-parties to the treaty fulfill the necessary conditions of compatible behaviour and opinio juris.") (italicization omitted); Baxter, supra note 98, at 278 (“[A]s is true of any rule extracted from the State practice of a number of nations, the force of the purported rule is enhanced or diminished by the absence or presence of conflicting practice on the part of other States.").

328. See Amnesty International, supra note 16, at 13.

329. Algeria, Argentina, Australia, Azerbaijan, Belgium, Bosnia, Brazil, Burundi, Cameroon, Canada, Chile, China, Comoros, Croatia, Cuba, Czech Republic, Denmark, El Salvador, Ethiopia, France, Jordan, Kazakhstan, Macedonia, Montenegro, Morocco, Netherlands, New Zealand, Norway, Panama, Paraguay, Peru, Romania, Somalia, Sri Lanka, Turkmenistan, Venezuela. Id. at 16-21.

330. G.A. Res. 34/3452 (XXX), annex, Declaration on the Protection of All Persons from Being Subjected to Torture and Other Cruel, Inhuman or Degrading Treatment or Punishment (Dec. 9, 1975).

331. Id., art. 7.

332. G.A. Res. 32/64, annex, Model Unilateral Declaration Against Torture and Other Cruel, Inhuman, or Degrading Treatment or Punishment (Dec. 8, 1977).

333. A/HRC/22/L.11. 
state-sponsored torture and constant call for its criminalization. Indeed, it seems to simply privilege scholarly perceptions of seriousness over the position that states themselves express - an argument that is the antithesis of positivism.

\section{B. Financing Terrorism}

If anything, the positivist case for considering financing terrorism to be an international crime is even stronger than the case for torture. To begin with, the 1999 Terrorist Financing Convention, which specifically requires each state party "[t]o establish as criminal offences under its domestic law the offences set forth in article 1," 334 is far more widely ratified than even the Torture Convention, with 187 states parties-every state in the world other than Burundi, Chad, Eritrea, Iran, Lebanon, Somalia, South Sudan, and Tuvalu. ${ }^{335}$ The sheer number of ratifications alone comes perilously close to satisfying the North Sea Continental Shelf standard, especially given that states parties include, with the exception of Lebanon and Iran, all of the states that most notoriously finance terrorism. But that is not all: not only have 151 states domestically criminalized terrorist financing along the lines required by Article 1, three of the nine states that have not ratified the Terrorist Financing Convention have nevertheless criminalized terrorist financing - a group that includes Iran. ${ }^{336}$

UN resolutions have also consistently emphasized the obligation to criminalize financing terrorism. Two unanimous Security Council resolutions are particularly relevant in this regard: Resolution 1373 (2001), which decided "that states shall . . . [c] ]riminalize the wilful provision or collection, by any means, directly or indirectly, of funds by their nationals or in their territories with the intention that the funds should be used, or in the knowledge that they are to be used, in order to carry out terrorist acts" 337 ; and Resolution 1456 (2003), which calls upon states to "comply fully" with their obligations under Res. $1373^{338}$ and to "become a party, as a matter of urgency, to all relevant international conventions and protocols relating to terrorism, in particular the 1999 international convention for the suppression of the financing of terrorism." 339 Similarly, the General Assembly

334. International Convention for the Suppression of the Financing of Terrorism, art. 4, Dec. 9, 1999, T.I.A.S. No. 13,075, 2178 U.N.T.S. 197.

335. For a list of states that have ratified the Terrorist Financing Convention, see U.N., Status of the International Convention for the Suppression of Terrorism Financing, https://treaties.un.org/Pages/ ViewDetails.aspx?src=IND\&mtdsg_no=XVIII-11\&chapter $=18 \&$ clang=_en (last updated Mar. 7, 2017).

336. See Chair of the S.C. Comm. Established Pursuant to Resolution 1373 (2001), Letter dated 18 Jan. 2016 from the Chair of the Security Council Established Pursuant to Resolution 1373 (2001) Concerning Counter-Terrorism addressed to the President of the Security Council, at 71, U.N. Doc. S/2016/ 49 (Jan. 20, 2016). The other criminalizing states are Lebanon and Tuvalu.

337. S.C. Res. 1373, para. 1(b) (Sept. 28, 2001).

338. SC Res. 1456, para. 1 (Jan. 20, 2003).

339. Id., para. 2(a). 
adopted Resolution 51/210 without a vote in 1997, calling upon states "[t]o take steps to prevent and counteract, through appropriate domestic measures, the financing of terrorists and terrorist organizations," 340 and adopted Resolution 68/276 without a vote in 2014, "[r]eiterating the obligation of Member States to prevent and suppress the financing of terrorist acts and to criminalize the wilful provision or collection, by any means, directly or indirectly, of funds by their nationals or in their territories, with the intention that the funds be used, or with the knowledge that they are to be used, in order to carry out terrorist acts." 341

Given the virtually universal criminalization of terrorist financing and these UN resolutions, "State practice, including that of States whose interests are specially affected," has been "both extensive and virtually uniform in the sense of the provision invoked" and has "occurred in such a way as to show a general recognition that a rule of law or legal obligation is involved." ${ }^{42}$ It thus seems clear that international law obligates all states, even those that have not ratified the Terrorist Financing Convention and might be inclined to be persistent objectors, to domestically criminalize financing terrorism-the basic requirement of the NCT. As a result, like state-sponsored torture, terrorist financing qualifies as an international crime: the existence of a jus cogens obligation to criminalize entitles states to exercise universal jurisdiction over terrorist financing, and the permissibility of universal jurisdiction entitles states to create an international tribunal capable of prosecuting any act of terrorist financing committed anywhere in the world.

\section{Other Crimes}

Similar positivist analyses could be conducted for a variety of other acts criminalized pursuant to suppression conventions. At least three conventions that require domestic criminalization of certain acts have been ratified by more than ninety-five percent of the world's states: the Chemical Weapons Convention $^{343}$ (192); the Illicit Traffic in Narcotics Convention ${ }^{344}$ (189); and the Safety of Civilian Aviation Convention 345 (188). Although beyond the scope of this Article, it is likely that close examination would reveal the same kind of "extensive and virtually uniform" post-adoption state practice that we see for torture and terrorist financing. If so, international law would

340. G.A. Res. 51/210, para. 3(f), Measures to Eliminate International Terrorism (Jan. 16, 1997).

341. G.A. Res. 68/276, pmbl., para. 14, The United Nations Global Counter-Terrorism Strategy Review (June 24, 2014).

342. North Sea Continental Shelf, supra note 62, at 44.

343. See Convention on the Prohibition, Development, Production, Stockpiling, and Use of Chemical Weapons and on Their Destruction, art. 7(1), Jan. 13, 1993, 1974 U.N.T.S. 45.

344. See United Nations Convention Against Illicit Traffic in Narcotic Drugs and Psychotropic Substances, art. 3(1), Dec. 20, 1988, 1582 U.N.T.S. 164.

345. See Convention for the Suppression of Unlawful Acts Against the Safety of Civilian Aviation, art. 3, Sept. 23, 1971, 24 U.S.T. 564, 974 U.N.T.S. 177. 
require all states to criminalize acts such as the use of chemical weapons, the cultivation of narcotics, and the destruction of aircraft, thereby permitting states to exercise universal jurisdiction over them individually or collectively via an international tribunal. Those acts would thus also qualify as international crimes.

\section{CONCLUSION}

International criminal law has always been haunted by the problem of consent. Almost without exception, states, international courts, and scholars have insisted that the defining feature of an international crime is its universality-both criminal and prosecutable no matter where in the world the act in question is committed. And that insistence is sound: in the post-Nuremberg era, it is difficult to accept the idea that international law could tolerate, say, a state systematically exterminating a racial, ethnic, or religious group simply because it refuses to criminalize genocide and is careful to ensure that genocide takes place solely within its borders.

Asserting that international crimes are universally criminal, however, does not explain how international law universally criminalizes. How could genocide be criminal everywhere, even in a state that insists the systematic extermination of its own people is legal? What justifies overriding state sovereignty and enforcing the prohibition of genocide in the face of such recalcitrance?

Since Nuremberg, one answer has dominated ICL: namely, that certain acts - international crimes-are directly criminalized by international law itself, making it irrelevant whether the territorial state considers those acts legal. If a state refuses to prosecute international crimes that are committed on its territory, the international community will do it for them, whether by states exercising universal jurisdiction themselves or via the creation of an international tribunal based on delegated universal jurisdiction.

That answer is both coherent and seductive. Unfortunately, as this Article has shown, it is also indefensible if we take positivism seriously-as every international tribunal since Nuremberg has insisted, if only in the breach, that we must. States have simply never endorsed the idea of direct criminalization: treaties do not affirm it; national incorporation of international crimes does not reflect it; UN resolutions do not endorse it; and universal jurisdiction is not based on it.

Direct criminalization, in short, is a naturalist idea, not a positivist onea well-intentioned but flawed concept created by the judges at Nuremberg, codified by the ILC, and championed by generations of scholars. If we want to ground ICL in positivism, we must accept a very different conception of an international crime: namely, as an act that international law obligates all states to domestically criminalize and prosecute. That conception, which I have called the national-criminalization thesis, explains universal criminality 
as well as the direct-criminalization thesis and explains universal jurisdiction far better. And unlike the DCT, the NCT has a solid basis in the actual practice of states.

International criminal law thus has two options. The first is to maintain fidelity to direct criminalization and openly acknowledge that the definition of an international crime is inherently naturalist. But that is unlikely to be an attractive option for most scholars - to say nothing of most judgesbecause naturalism has come to be seen (rightly) as synonymous with a degree of subjectivity and indeterminacy that is antithetical to ICL's legitimacy. For good or for ill, we are (almost) all positivists now.

The second and more plausible option, then, is for ICL to accept the NCT. That option has the virtue of maintaining fidelity to positivism, thereby avoiding the dead end of naturalist debate: the inevitable scholarly disagreement over what acts are so impermissible that they should be considered international crimes. Yet the NCT also has two significant drawbacks, one practical and one theoretical. The practical drawback, which is likely to make it a undesirable option for most judges and scholars-though a desirable one for states-is that the NCT not only challenges the idea that aggression is an international crime (much less the "supreme international crime"), ${ }^{346}$ but also destabilizes the distinction ICL has traditionally drawn between international and transnational crimes, significantly expanding the category of acts that should be considered "true" international crimes.

The theoretical drawback is less evident, but for that very reason all the more important to acknowledge: that it is possible, perhaps even likely, that even the NCT is methodologically underdetermined. As we have seen, strict adherence to positivism requires the existence of jus cogens norms-for the obligation to criminalize no less than for direct criminalization. It may be too strong to insist, with Mégret, that such norms should be seen as "participating in the creation of a peremptory supranational legal order and gradually emulating the old naturalist idea that there are binding norms over and above, but most importantly independently of, sovereignty." ${ }^{447}$ But there is no question that the evidentiary requirements for jus cogens norms remain opaque - and that precious few customary rules will qualify as jus cogens if we take those (opaque) evidentiary requirements seriously. As a result, even the NCT, with its superior positivist foundation compared to the DCT, might be incapable of banishing naturalism entirely. ${ }^{348}$ Indeed, it is quite possible that a residuum of naturalism - the need to nudge customary rules

346. IMT Judgment, supra note 57 , at 421.

347. Frédéric Mégret, The Creation of the International Criminal Court and State Sovereignty: The "Problem of an International Criminal Law" Re-Examined, in 3 International Humanitarian Law: Prospects 47, 91 (John Carey et al. eds., 2006) (footnote omitted).

348. See, e.g., Jean D’Aspremont, Formalism and the Sources of International Law 15 (2011) (" $[T]$ he formal identification of rules through a standard pedigree does not entirely stifle indeterminacy at the level of law-ascertainment. On the contrary, formalism inevitably brings about some indeterminacy."). 
over the jus cogens line-is simply inherent in ICL's understandable quest for universality. To paraphrase William James: when it comes to the existence of international crimes, it may be turtles all the way down. ${ }^{349}$

349. The expression refers to the idea that all knowledge is perspectival, making objective knowledge an unrealizable ideal. See, e.g., Isabelle Stengers, Power and Invention: Situating Science 62 (1997). 


\section{APPENDIX 350}

States that make use of universal jurisdiction only when required or permitted by treaty.

Andorra
Argentina
Azerbaijan
Belarus
B51
Belize
Bolivia
Brazil
Bulgaria
China
Colombia ${ }^{352}$
Cyprus
Gambia
Georgia
Ghana
Grenada
Guatemala
Haiti
India
Iran ${ }^{353}$
Ireland
Jamaica
Japan
Kenya
Kiribati
Kuwait
Lesotho
Liberia
Luxembourg
Malawi

350. All categorizations are based on AmNeSty InTERnAtional, supra note 16, unless otherwise indicated.

351. Statement submitted by Belarus, reply to Sixty-Fifth U.N. G.A. on Universal Jurisdiction, supra note 18, at 3, http://www.un.org/en/ga/sixth/65/ScopeAppUniJuri_StatesComments/Belarus_E.pdf.

352. Statement submitted by Colombia, reply to Sixty-Sixth U.N. G.A. on Universal Jurisdiction,, supra note 19, at 6, http://www.un.org/en/ga/sixth/66/ScopeAppUniJuri_StatesComments/ Colombia\%20(S\%20to\%20E).pdf.

353. Statement of Iran, 12th Meeting 2014, supra note 267, at 7.

354. Statement submitted by Kenya, reply to Sixty-Fifth U.N. G.A. on Universal Jurisdiction, supra note 18, at 1, http://www.un.org/en/ga/sixth/65/ScopeAppUniJuri_StatesComments/Kenya.pdf. 
Malaysia $^{355}$

Mali

Mauritius

Mexico

Moldova ${ }^{356}$

Mongolia

Mozambique

Namibia

New Zealand

Nicaragua

Nigeria

Papua New Guinea

Paraguay

Peru

Qatar ${ }^{357}$

Russian Federation

Saint Kitts and Nevis

St. Lucia

Samoa

Seychelles

Sierra Leone

Singapore

Slovenia

Solomon Islands

Tanzania

Timor-Leste

Trinidad and Tobago

Tunisia

Tuvalu

Uganda

Ukraine

United Kingdom ${ }^{358}$

United States

Uzbekistan

Vietnam

355. Statement submitted by Malaysia, reply to Sixty-Fifth U.N. G.A. on Universal Jurisdiction, supra note 18, at 3, http://www.un.org/en/ga/sixth/65/ScopeAppUniJuri_StatesComments/Malaysia.pdf. 356. Statement submitted by Moldova, reply to U.N. Secretary-General, The Scope and Application of the Principle of Universal Jurisdiction, Sixty-Eighth Session of the General Assembly U.N. Doc. A/68/113 (2013) [hereinafter Sixty-Eight U.N. G.A. on Universal Jurisdiction] at 12, http://www.un.org/en/ga/ sixth/68/UnivJur/Moldova.pdf.

357. U.N. Secretary-General, The Scope and Application of the Principle of Universal Jurisdiction, para. 30 , U.N. Doc. A/66/93 (June 20, 2011) [hereinafter 2011 S.G. Report].

358. Statement submitted by United Kingdom, reply to Sixty-Sixth U.N. G.A. on Universal Jurisdiction, supra note 19, at 4, http://www.un.org/en/ga/sixth/66/ScopeAppUniJuri_StatesComments/ UK\&Northern\%20Ireland.pdf. 


\section{Zimbabwe}

States that view universal jurisdiction as a subsidiary jurisdictional form. States that require double criminality, as well, are in bold.

Algeria
Angola
Argentina
Australia $^{360}$
Austria
Azerbaijan
Belgium
Benin
Bosnia
Brazil
Burundi
Cameroon
Canada
Chile
China
Colombia
Comoros
Congo
Cote d'Ivoire
Croatia ${ }^{368}$
Cuba $^{369}$
Czech Republic
Denmark

359. Statement of Argentina, Sixth Committee, Summary Record of the 12th Meeting 12 [hereinafter 12th Meeting 2011], U.N. Doc. A/C.6/69/SR.12 (Nov. 16, 2011).

360. Statement of Australia, Sixth Committee, Summary Record of the 11th Meeting 2, [hereinafter 11 th Meeting 2014], U.N. Doc. A/C.6/69/SR.11 (Nov. 6, 2014).

361. ILC Extradite or Prosecute Paper, supra note 91, at 33.

362. Statement of Azerbaijan, 12th Meeting 2014, supra note 267, at 3.

363. Statement of Brazil, 11th Meeting 2014, supra note 360, at 6.

364. Statement of Canada, 11th Meeting 2014, id. at 2.

365. Statement submitted by Chile, reply to Sixty-Fifth U.N. G.A. on Universal Jurisdiction, supra note 18, at 3, http://www.un.org/en/ga/sixth/65/ScopeAppUniJuri_StatesComments/Chile_E.pdf.

366. Statement submitted by China, reply to Sixty-Fifth U.N. G.A. on Universal Jurisdiction, supra note 18, at 5, http://www.un.org/en/ga/sixth/65/ScopeAppUniJuri_StatesComments/China_E.pdf.

367. Statement submitted by Colombia, reply to Sixty-Sixth U.N. G.A. on Universal Jurisdiction, supra note 19, at 4, http://www.un.org/en/ga/sixth/66/ScopeAppUniJuri_StatesComments/ Colombia\%20(S\%20to\%20E).pdf.

368. Statement of Croatia, Sixth Committee, Summary Record of the 13th Meeting 2, U.N. Doc. A/ C.6/70/SR.13 (Oct. 30, 2015).

369. U.N. Secretary-General, The Scope and Application of the Principle of Universal Jurisdiction, para. 43, U.N. Doc. A/68/113 (June 26, 2013).

370. Statement submitted by Czech Republic, reply to Sixty-Fifth U.N. G.A. on Universal Jurisdiction, supra note 18 , at 1 , http://www.un.org/en/ga/sixth/65/ScopeAppUniJuri_StatesComments/ Czech\%20Republic.pdf. 


\author{
Egypt $^{371}$ \\ El Salvador ${ }^{372}$ \\ Ethiopia $^{373}$ \\ France \\ Germany \\ Guinea \\ Hungary \\ Iceland \\ Israel $^{374}$ \\ Jordan ${ }^{375}$ \\ Kazakhstan \\ Kenya ${ }^{376}$ \\ Lebanon $^{377}$ \\ Lesotho $^{378}$ \\ Macedonia \\ Malaysia $^{379}$ \\ Montenegro \\ Morocco $^{380}$ \\ Netherlands ${ }^{381}$ \\ New Zealand ${ }^{382}$ \\ Nigeria ${ }^{383}$ \\ Norway ${ }^{384}$ \\ Panama ${ }^{385}$ \\ Paraguay $^{386}$ \\ Peru $^{387}$
}

371. Statement of Egypt, 13th Meeting 2015, supra note 368, at 2.

372. Statement of El Salvador, 11th Meeting 2014, supra note 360, at 9.

373. Statement submitted by Ethiopia, reply to Sixty-Fifth U.N. G.A. on Universal Jurisdiction, supra note 18, at 1, http://www.un.org/en/ga/sixth/65/ScopeAppUniJuri_StatesComments/Ethiopia.pdf.

374. Statement submitted by Israel, reply to Sixty-Fifth U.N. G.A. on Universal Jurisdiction, supra note 18, at 3, http://www.un.org/en/ga/sixth/65/ScopeAppUniJuri_StatesComments/Israel.pdf.

375. Statement of Jordan, 12th Meeting 2014, supra note 267, at 6.

376. Statement of Kenya, Sixth Committee, Summary Record of the 12th Meeting 14, U.N. Doc. A/ C.6/70/SR.12 (Nov. 5, 2015).

377. 2011 S.G. Report, supra note 357, para. 146.

378. Statement of Lesotho, Sixth Committee, Summary Record of the 12th Meeting 10, U.N. Doc. A/C.6/67/SR.12 (Dec. 6, 2012).

379. Statement submitted by Malaysia, reply to Sixty-Fifth U.N. G.A. on Universal Jurisdiction, supra note 18, at 1, http://www.un.org/en/ga/sixth/65/ScopeAppUniJuri_StatesComments/Malaysia.pdf. 380. Statement of Morocco, 12th Meeting 2014, supra note 267, at 4.

381. Ariana Pearlroth, Universal Jurisdiction in the European Union: Country Studies 26 (2003).

382. Statement of New Zealand, 11th Meeting 2014, supra note 360, at 2.

383. Statement of Nigeria, 12th Meeting 2014, supra note 267, at 2.

384. Statement of Norway, 12th Meeting 2012, supra note 376, at 10.

385. U.N. Secretary-General, The Scope and Application of the Principle of Universal Jurisdiction, para. 39, U.N. Doc. A/67/116 (June 28, 2012).

386. 2011 S.G. Report, supra note 357, para. 71

387. Statement of Peru, 11th Meeting 2014, supra note 360, at 8 . 


\section{Romania}

Serbia $^{388}$

Singapore 389

Slovakia ${ }^{390}$

Slovenia $^{391}$

Somalia

Sri Lanka ${ }^{392}$

Switzerland ${ }^{393}$

Turkmenistan

Venezuela ${ }^{394}$

Vietnam ${ }^{395}$

388. Criminal Code of the Republic of Serbia, art. 9, http://www.osce.org/serbia/18244? download= true (last visited Mar. 8, 2017).

389. Statement of Singapore, supra note 359 at 8.

390. 2011 S.G. Report, supra note 357, para. 155.

391. Statement submitted by Slovenia, reply to Sixty-Fifth U.N. G.A. on Universal Jurisdiction, supra note 18, at 1, http://www.un.org/en/ga/sixth/66/ScopeAppUniJuri_StatesComments/Slovenia.pdf.

392. Statement of Sri Lanka, 11th Meeting 2014, supra note 360, at 13.

393. Statement submitted by Switzerland, reply to Sixty-fifth U.N. G.A. on Universal Jurisdiction, supra note 18, at 3, http://www.un.org/en/ga/sixth/66/ScopeAppUniJuri_StatesComments/ Switzerland $\% 20(\mathrm{~F} \% 20$ to $\% 20 \mathrm{E})$.pdf.

394. Statement of Venezuela, 12th Meeting 2015,12th Meeting 2015, supra note 376.

395. Statement of Vietnam, 12th Meeting 2015, supra note 376, at 10. 